Ethier, D., P. Davidson, G. H. Sorenson, K. L. Barry, K. Devitt, C. B. Jardine, D. Lepage, and D. W. Bradley. 2020. Twenty years of coastal waterbird trends suggest regional patterns of environmental pressure in British Columbia, Canada. Avian Conservation and Ecology 15(2):20. https:// doi.org/10.5751/ACE-01711-150220

Copyright (C) 2020 by the author(s). Published here under license by the Resilience Alliance.

Research Paper

\title{
Twenty years of coastal waterbird trends suggest regional patterns of environmental pressure in British Columbia, Canada
}

\author{
Danielle Ethier $^{1}$, Pete Davidson ${ }^{1}$, Graham H. Sorenson ${ }^{1}$, Karen L. Barry ${ }^{2}$, Karen Devitt ${ }^{3}$, Catherine B. Jardine ${ }^{1}$, Denis Lepage ${ }^{1}$ and \\ David W. Bradley ${ }^{1}$ \\ ${ }^{1}$ Birds Canada, ${ }^{2}$ Habitat Conservation Trust Foundation, ${ }^{3}$ City of Port Moody, British Columbia
}

\begin{abstract}
Waterbirds are often used as indicators of ecosystem function across broad spatial and temporal scales. Resolving which species are declining and the ecological characteristics they have in common can offer insights into ecosystem changes and their underlying mechanisms. Using 20 years of citizen science data collected by the British Columbia Coastal Waterbird Survey, we examine species-specific trends in abundance of 50 species in the Salish Sea and 37 species along the outer Pacific Ocean coast that we considered to form the core wintering coastal bird community of British Columbia, Canada. Further, we explore whether ecological commonalities increase the likelihood of a species undergoing declines by testing the hypotheses that waterbird abundance trends are influenced by dietary specialization and migration distance to breeding grounds. Results suggest that most populations are stable (i.e., temporal trends are not significant) in both the Salish Sea (36 of $50 \mathrm{spp}$.) and Pacific coast ( 32 of $37 \mathrm{spp}$.) regions. Twelve species displayed significant decline trends in the Salish Sea, whereas two had significant increases. Along the Pacific coast, only three species displayed significant decline trends, and two significant increases. This result is corroborated by guild-specific trends indicating that waterbirds occupying the Salish Sea are faring significantly worse than those residing along the outer coastal regions, almost irrespective of dietary specialization or migration distance. Our results provide evidence that differential environmental pressures between the inner and outer coastal regions may be causing overall loss of wintering waterbirds within, or abundance shifts away from, the Salish Sea. Potential mechanisms responsible for these observed patterns are discussed, including environmental (e.g., climate) and human-induced (e.g., nutrient and chemical pollution) pressures. Collaborative, inter-disciplinary research priorities to help understand these mechanisms are suggested.
\end{abstract}

\section{Vingt ans de suivi d'oiseaux aquatiques côtiers montrent des tendances régionales de pressions environnementales en Colombie-Britannique, Canada}

RÉSUMÉ. Les oiseaux aquatiques sont souvent utilisés comme indicateurs du fonctionnement des écosystèmes à de larges échelles spatiales et temporelles. La détermination des espèces en diminution et des caractéristiques écologiques qu'elles ont en commun permet de se faire une idée des changements dans les écosystèmes et des mécanismes sous-jacents. Au moyen de 20 ans de données de science citoyenne collectées lors du Coastal Waterbird Survey de la Colombie-Britannique, nous avons examiné les tendances dans l'abondance de 50 espèces dans la mer des Salish et de 37 espèces plus au large de la côte de l'océan Pacifique que nous avons considérées comme formant le noyau de la communauté d'oiseaux côtiers hivernant de la Colombie-Britannique, au Canada. En outre, nous avons étudié si les traits communs écologiques augmentaient la probabilité qu'une espèce subisse une baisse en testant les hypothèses selon lesquelles les tendances de l'abondance des oiseaux aquatiques étaient influencées par la spécialisation alimentaire et la distance de migration vers les sites de reproduction. Selon nos résultats, la plupart des populations étaient stables (c.-à-d. que les tendances temporelles n'étaient pas significatives) dans la mer des Salish (36 sur $50 \mathrm{sp}$.) et le long de la côte du Pacifique (32 sur $37 \mathrm{sp}$.). Douze espèces ont montré une tendance significative de diminution dans la mer des Salish, tandis que deux ont connu des augmentations significatives. Le long de la côte du Pacifique, seules trois espèces ont affiché une tendance à la baisse significative, et deux des augmentations significatives. Ce résultat est corroboré par les tendances propres à chaque guilde indiquant que les oiseaux aquatiques qui occupent la mer des Salish se portent nettement moins bien que ceux qui se tiennent plus au large des côtes, presque indépendamment de leur spécialisation alimentaire ou de leur distance de migration. Nos résultats montrent que les pressions environnementales variables entre les parties intérieures et extérieures des régions côtières peuvent être à l'origine de la perte globale des oiseaux aquatiques hivernant dans la mer des Salish ou d'un déplacement de ces oiseaux vers d'autres régions. Nous avons examiné les possibles mécanismes responsables des tendances observées, y compris les pressions environnementales (p. ex. le climat) et humaines (p. ex. la pollution par les nutriments et les produits chimiques). Enfin, nous proposons des priorités de recherche collaborative et interdisciplinaire pour faciliter la compréhension de ces mécanismes.

Key Words: British Columbia; Citizen Science; coastal; monitoring; overwintering; Pacific; population trends; waterbirds; waterfowl

Address of Correspondent: Danielle Ethier, P.O. Box 160, 115 Front Road, Port Rowan, ON Canada N0E 1M0, Phone: 519-586-3531 ext. 115, dethier@birdscanada.org 


\section{INTRODUCTION}

Human impacts on marine ecosystems are complex and widespread. Activities such as commercial fishing (e.g., Thrush et al. 1998), pollution (e.g., Kennish 2002), and climate change (e.g., Harley et al. 2006) affect a diverse suite of flora and fauna, leading to complex and varying consequences for marine biodiversity. Unravelling these dynamic relationships and identifying the mechanisms driving declines in marine biodiversity continue to challenge ecologists (Möllmann and Diekmann 2012, Gamfeldt et al. 2015). Comprehensive long-term monitoring programs that track ecosystem-wide trends in biodiversity and abundance are invaluable to this process because they provide information about species in decline, their commonalities, and correlations with the hypothesized responsible drivers. Waterbirds are often considered to be ideal indicators of changes in marine productivity and ecosystem function across broad spatial and temporal scales because they are typically long-lived, migratory, and higher trophic-level feeders (Ainley and Hyrenbach 2010, Vilchis et al. 2015). Trends in waterbird abundance can therefore offer insights into ecosystem changes happening locally and beyond and the conservation measures necessary to mitigate them.

The coastline of British Columbia (BC), Canada, is home to diverse and plentiful marine life, including many globally important staging, molting, and wintering areas for waterbirds that migrate along the Pacific Flyway (e.g., Important Bird and Biodiversity Areas in Canada: https://www.ibacanada.com/). The Salish Sea supports 172 bird species that are dependent on the region's habitats, of which 72 are highly dependent on intertidal and marine habitats (Gaydos et al. 2008, Gaydos and Pearson 2011). This coastline also supports large urban populations, specifically in the south (e.g., Greater Vancouver Region), and maintains a strong economy based on ocean-based industries, which contribute $\$ 11$ billion (8\%) to the provincial gross domestic product (Stocks and Vandeborne 2017). Over the past two decades, the coastal human population of BC has increased by approximately 15,000 people/yr (1.21\%; BC Stats 2020), which is coupled with the expansion of ocean-based industries, including (in order of importance): recreation, transportation, and seafood (Stocks and Vandeborne 2017). Along with the effects of global climate change on ocean productivity (e.g., Moore et al. 2018), BC's coastal and marine ecosystems are experiencing increasing pressures. Waterbird species that overwinter along BC's coastline have similarly experienced significant changes in abundance in recent decades (Anderson et al. 2009, Bower 2009, Crewe et al. 2012), the causes of which remain largely unresolved. In 1999, Birds Canada (formerly Bird Studies Canada) began the British Columbia Coastal Waterbird Survey (BCCWS) to collect baseline information on the status of waterbirds along the $\mathrm{BC}$ coast so that the impacts of natural and human-induced environmental change could be assessed through time.

Here, we provide an update to the species-specific trend analysis done by Crewe et al. (2012) that marks 20 years of data collection by the BCCWS. In addition to analyzing abundance trends of species occupying the Canadian extent of the Salish Sea (inner coastal), we also assess trends from the outer coastal region of the Pacific Ocean (see Methods: Study area) to gain insight into the differential pressures facing birds using the two regions. Further, our analysis assesses the ecological characteristics associated with species- and guild-specific trends in the Salish Sea and along the outer Pacific coast. Specifically, we hypothesized that abundance trends in waterbirds are influenced by dietary specialization and migration distance. First, we predicted that abundance declines will be more prevalent in higher tropic feeders because this guild is generally more responsive to shifts in the availability and quality of prey (e.g., Ballance et al. 1997, Hyrenbach and Veit 2003, Ainley and Hyrenbach 2010, Vilchis et al. 2015). Second, we predicted that abundance declines will be more pronounced in migrants because these populations are able to shift their range in response to resource availability more readily than local breeders can (e.g., Burger and Gochfeld 1991, Marks and Redmond 1994, Willie et al. 2020). Finally, we discuss potential mechanisms to stimulate future research and to inform conservation planning.

\section{METHODS}

\section{Study area}

The survey area extends from the north of Graham Island $\left(54^{\circ}\right.$ $\left.02^{\prime} 36.3^{\prime \prime} \mathrm{N}, 131^{\circ} 54^{\prime} 38.3^{\prime \prime} \mathrm{W}\right)$ to the southern tip of Vancouver Island, Canada $\left(48^{\circ} 19^{\prime} 04.3^{\prime}\right.$ N, $123^{\circ} 33^{\prime} 28.6$ " W; Fig. 1). There are 326 survey routes in total, which cover a wide variety of habitat types, including: rocky shores, sandy beaches, salt marshes, mudflats, fast-flowing channels, and other inshore waters. The $\mathrm{BC}$ coast experiences the mildest winters in all of Canada, with temperatures rarely dropping below freezing (https://www. welcomebc.ca/Choose-B-C/Explore-British-Columbia/Climate-of$\mathrm{B}-\mathrm{C})$. As a result, offshore and most inshore waters never freeze completely, making the coastline and freshwater inflows attractive to many wintering waterbirds that breed inland and further north.

Fig. 1. Map of the British Columbia Coastal Waterbird Survey (BCCWS) study area in British Columbia, Canada. The study area was divided into two district regions: the inner coastal waters of the Salish Sea (A), and the outer costal waters of the Pacific Ocean (B). Red dots denote the location of survey routes used to collect standardized counts of waterbirds from 1999-2019.

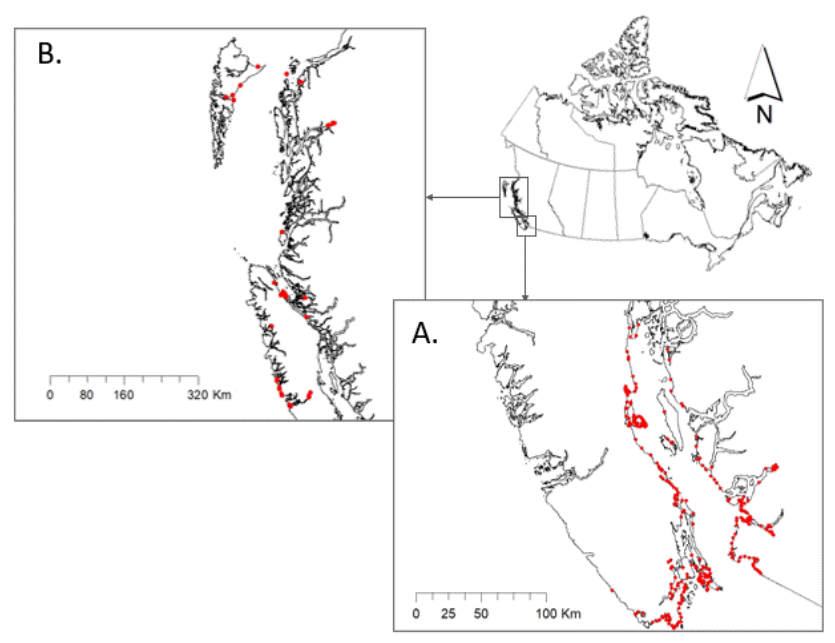


We divided the study area into two distinctive regions: (1) the Canadian extent of the Salish Sea (hereafter, Salish Sea), and (2) the outer coastal region of the Pacific Ocean (hereafter, Pacific coast). The Salish Sea survey routes are within the Straits of Georgia and Juan de Fuca (Fig. 1A) and are comparable to those used by Crewe et al. (2012) to permit direct trend comparison. This region faces disproportionately high levels of environmental pressure caused by the region's large and rapidly growing human population and ocean-based industries (Georgia Strait Alliance, About the Strait: https://georgiastrait.org/issues/about-thestrait-2/). The Pacific coast survey routes are those along the west coast of Vancouver Island and routes within the Johnstone and Hecate Straits (Fig. 1B). These coastal regions are sparsely populated by rural coastal communities and experience substantially less commercial and industrial pressure (Stocks amd Vandeborne 2017).

\section{Data collection}

From 1999-2019, surveys were conducted by volunteers using a standardized protocol and data collection sheets (Birds Canada 2018). Shore-based counts were completed monthly on or near the second Sunday of each month from September to April. Surveys were completed within approximately $2 \mathrm{~h}$ of high tide to maximize the opportunity for close observation. All waterbirds observed to a distance of $1 \mathrm{~km}$ from the high tide line were counted, except those that flew through without stopping. In the case of larger flocks, numbers were estimated by counting individuals and species in groups and scaling up (see Birds Canada 2013). Surveyors varied within and among years, and because skill level was not recorded, observer skill was assumed to vary randomly and not systematically over time. Data were entered through a customized online data entry system available on the Birds Canada website, NatureCounts (https://www.birdscanada. org/birdmon/default/main.jsp). Observations were processed using the eBird data filters to flag rare species and high counts during observer data entry (Cornell Laboratory help center: https://support.ebird.org/en/support/solutions/articles/48000795278the-ebird-review-process), and records were manually reviewed for form accuracy.

\section{Analysis metric}

The basic statistical unit for all analyses was the mean count of each species on a survey route across months within the speciesspecific survey window. Species-specific survey windows were assigned based on local knowledge of the months in the nonbreeding season that each species is most prevalent (Appendix 1). For example, the mean route-level count of Canada Goose (Branta canadensis) in a given year was calculated based on the sum of monthly counts in December, January, and February divided by the total number of months $(N=3)$. Only routes surveyed a minimum of 5 years and with $100 \%$ monthly coverage within the species-specific survey window were included in the analyses (e.g., December-February for most wintering birds). Because our aim was to focus on species that are persistent, abundant, and biologically associated with the study area, we excluded rarely detected species from our analyses (i.e., species with $>85 \%$ zero counts across all routes and years, species that had a mean abundance per year $<10$, and species that were detected in fewer than one-half of the survey years). Counts of Greater Scaup (Aythya marila) and Lesser Scaup (A. affinis) were combined for the analysis (Scaup spp.) because of model convergence issues when they were run independently, which were resolved when counts were combined. In general, A. marila is much more numerous than $A$. affinis along BC coastlines in winter (e.g., Badzinski et al. 2006). The resulting data set included an ecologically and phylogenetically diverse suite of 50 species in the Salish Sea and 37 species along the outer Pacific coast that we considered the core wintering coastal waterbird community of the BCCWS (Table 1). Based on Davidson et al. (2015) and expert review, we categorized migration distance for each species as: (1) local, i.e., regularly breeding in at least small numbers within the study area catchment, (2) short distance, i.e., regularly breeding in at least small numbers in the interior of $\mathrm{BC}$, adjacent northwestern United States, or the southeast Alaskan coast, or (3) long-distance migrant, i.e., breeding in the northern Boreal and Arctic regions of North America. Species were also classified based on their dietary specialization following Bower (2009) and Billerman et al. (2020) as being benthivorous, piscivorous, herbivorous, or omnivorous (Appendix 1).

\section{Trends analysis}

Twenty-year trends in counts were estimated independently for each species and region using a Bayesian framework with integrated nested Laplace approximation (INLA; Rue et al. 2009) in R (version 3.5.3; R Core Team 2014). Model comparison using leave-one-out cross-validation in INLA was used to select between a Poisson and negative binomial distribution (Held et al. 2010). Count data were fit using a log-linear regression model for each species that included a continuous effect for year $(t)$ to estimate the change in population size on a given route $(j)$ over time (i.e., linear trend), a hierarchical first-order autoregressive term to model the temporal autocorrelation structure of residuals among years $(\gamma)$, and an independent and identically distributed hierarchical term to account for random variation in counts among routes $(\eta)$.

$$
\log \left(\mu_{t j}\right)=\alpha+\beta_{1} * \text { year }_{t j}+\gamma_{t}+\eta_{j}
$$

The number of routes detecting a species each year was included as an offset to account for variable count effort and distributional differences across the study area. The continuous year coefficients and credible intervals were transformed into constant rates of population change using $100 \times(\exp ($ estimate $)-1)$. Annual indices of population size for each species were derived from the model for the full 20-yr monitoring period. The analytical approach applied here follows that of Crewe et al. (2012) to enable more direct comparison of trends, with some adjustment to improve analytical rigor. Specifically, both methods used a log-linear regression model with continuous year and categorical route-level effects. Our model differed in that we deployed our analysis in a Bayesian framework and included additional hierarchical terms to account for residual variation and an offset to account for variation in sampling effort. The inclusion of a hierarchical term here better accounts for temporal autocorrelation structure of residuals among years, thus allowing the model to better meet the assumption of sampling independence. Ignoring this dependency can make the estimates of standard error too small. Further, the addition of an offset better ensures that changes in effort are accounted for during the analysis of trends. 
Table 1. Annual population trends for 50 coastal waterbird species overwintering in the Salish Sea (inner coastal) and 37 species in the outer coast regions of the Pacific Ocean in British Columbia, Canada, from 1999-2019 and 1999-2011 (Crewe et al. 2012). Bold font indicates species for which a statistically significant annual trend (\%/yr) is implied, i.e., lower credibility intervals (LCI) and upper credibility intervals (UCI) do not contain zero.

\begin{tabular}{|c|c|c|c|c|c|c|c|c|}
\hline \multirow[t]{2}{*}{ Common name } & \multirow[t]{2}{*}{ Scientific name } & \multicolumn{3}{|c|}{ Salish Sea (1999-2019) } & \multicolumn{3}{|c|}{ Pacific coast (1999-2019) } & \multirow{2}{*}{$\begin{array}{c}\text { Salish Sea (1999-2011) } \\
\text { Trend }^{\dagger}\end{array}$} \\
\hline & & Trend & LCI & $\mathrm{UCI}$ & Trend & LCI & $\mathrm{UCI}$ & \\
\hline$\overline{\text { Brant }^{\dagger}}$ & Branta bernicla & +0.10 & -5.92 & +5.44 & & & & -4.70 \\
\hline Canada Goose & Branta canadensis & +4.92 & +2.84 & +7.04 & +1.91 & -5.82 & +9.96 & -8.90 \\
\hline Trumpeter Swan $^{\dagger}$ & Cygnus buccinator & -8.24 & -12.01 & -4.40 & -1.49 & -11.49 & +8.00 & -5.50 \\
\hline Gadwall & Mareca strepera & -0.30 & -5.07 & +4.92 & & & & -7.30 \\
\hline Eurasian Wigeon & Mareca penelope & -1.98 & -9.43 & +6.72 & +14.11 & -5.54 & +37.03 & +5.70 \\
\hline American Wigeon $^{\dagger}$ & Mareca americana & +1.31 & -0.90 & +3.67 & +9.20 & -2.76 & +23.24 & +1.20 \\
\hline Mallard & Anas platyrhynchos & +1.01 & -1.39 & +3.56 & +3.67 & -3.73 & +9.97 & -1.10 \\
\hline Northern Pintail $^{\dagger}$ & Anas acuta & -2.96 & -14.70 & +8.76 & +15.37 & -5.92 & +41.20 & -2.60 \\
\hline Green-winged Teal & Anas crecca & -0.70 & -3.82 & +2.74 & +7.79 & -4.59 & +21.05 & -7.90 \\
\hline Ring-necked Duck & Aythya collaris & +10.63 & +5.13 & +15.95 & & & & +4.70 \\
\hline Scaup spp. & Scaup sp. & -10.68 & -13.58 & -7.69 & -8.15 & -28.82 & +16.77 & $\begin{array}{l}\text { Greater } \mathbf{- 9 . 8 0} \\
\text { Lesser } \mathbf{- 1 4 . 5 0}\end{array}$ \\
\hline Harlequin Duck $^{\dagger}$ & Histrionicus histrionicus & -0.70 & -1.98 & +0.70 & -4.97 & -11.40 & +2.22 & -2.60 \\
\hline Surf Scoter ${ }^{\dagger}$ & Melanitta perspicillata & -2.27 & -4.02 & -0.50 & +3.77 & -9.79 & +17.00 & -7.60 \\
\hline White-winged Scoter ${ }^{\dagger}$ & Melanitta deglandi & -4.30 & -7.50 & -0.60 & +7.57 & -4.02 & +20.68 & -7.60 \\
\hline Black Scoter & Melanitta americana & -14.96 & -18.29 & -11.49 & & & & -19.20 \\
\hline Long-tailed Duck & Clangula hyemalis & $-\mathbf{5 . 0 7}$ & -8.42 & -1.59 & +6.72 & -3.54 & +19.84 & -7.00 \\
\hline Bufflehead & Bucephala albeola & +0.60 & -1.09 & +2.63 & +1.11 & -5.54 & +8.44 & -0.70 \\
\hline Common Goldeneye & Bucephala clangula & -0.50 & -2.37 & +1.31 & +5.23 & -4.11 & +13.20 & -0.20 \\
\hline Barrow's Goldeneye & Bucephala islandica & -2.37 & -4.88 & +1.31 & -8.15 & -14.87 & -0.60 & -4.30 \\
\hline Hooded Merganser & Lophodytes cucullatus & -0.90 & -3.82 & +2.02 & -5.82 & -9.34 & -2.08 & \\
\hline Common Merganser & Mergus merganser & +2.94 & -0.60 & +6.93 & +0.60 & -8.06 & +8.22 & +1.70 \\
\hline Red-breasted Merganser $^{\dagger}$ & Mergus serrator & -0.70 & -3.25 & +2.12 & -1.19 & -6.85 & +4.29 & -0.60 \\
\hline Horned Grebe & Podiceps auritus & +1.51 & -2.18 & +4.92 & +6.40 & -2.57 & +15.26 & -2.60 \\
\hline Red-necked Grebe ${ }^{\dagger}$ & Podiceps grisegena & +1.92 & -4.40 & +9.53 & +7.57 & +1.31 & +13.20 & -2.90 \\
\hline Western Grebe $^{\dagger}$ & Aechmophorus occidentalis & -12.72 & -17.47 & -7.69 & -0.80 & -14.02 & +14.00 & -16.40 \\
\hline Black Oystercatcher $^{\dagger}$ & Haematopus bachmani & +1.21 & -3.92 & +4.81 & & & & +0.90 \\
\hline Black-bellied Plover $^{\dagger}$ & Pluvialis squatarola & -2.18 & -8.52 & +3.77 & & & & -4.00 \\
\hline Killdeer & Charadrius vociferus & +2.22 & -4.69 & +9.09 & +7.90 & -7.87 & +26.49 & -2.60 \\
\hline Black Turnstone $^{\dagger}$ & Arenaria melanocephala & -4.21 & -7.87 & -0.90 & +0.70 & -9.24 & +11.74 & +0.40 \\
\hline Surfbird $^{\dagger}$ & Calidris virgata & -5.54 & -14.44 & +4.39 & & & & -18.10 \\
\hline Dunlin $^{\dagger}$ & Calidris alpina & -9.70 & -13.06 & -6.01 & +5.76 & -11.13 & +25.48 & -8.90 \\
\hline Greater Yellowlegs & Tringa melanoleuca & -4.21 & -9.24 & +1.21 & & & & -10.50 \\
\hline Common Murre & Uria aalge & +3.15 & -3.92 & +10.85 & +13.66 & +0.70 & +28.40 & +3.80 \\
\hline Pigeon Guillemot & Cepphus columba & -3.54 & -10.95 & +4.39 & +16.65 & -0.60 & +38.13 & +21.70 \\
\hline Marbled Murrelet $^{\dagger}$ & Brachyramphus marmoratus & +3.36 & -1.29 & +8.00 & -7.50 & -16.72 & +2.74 & -4.40 \\
\hline Bonaparte's Gull $^{\dagger}$ & Chroicocephalus philadelphia & -2.47 & -9.79 & +5.55 & & & & -12.90 \\
\hline Heermann's Gull & Larus heermanni & -3.82 & -13.93 & +7.04 & & & & \\
\hline Mew Gull & Larus canus & -4.59 & -10.33 & -0.50 & +4.50 & -3.54 & +12.98 & -2.50 \\
\hline Ring-billed Gull & Larus delawarensis & -2.57 & -7.32 & +2.53 & & & & -0.90 \\
\hline California Gull & Larus californicus & +1.01 & -5.45 & +8.00 & & & & -8.90 \\
\hline Thayer's Gull ${ }^{\dagger}$ & Larus glaucoides & -3.54 & -7.60 & +0.60 & -4.11 & -18.21 & +12.86 & -4.10 \\
\hline Glaucous-winged Gull ${ }^{\dagger}$ & Larus glaucescens & -0.90 & -3.44 & +1.41 & -2.27 & -8.70 & +4.08 & -4.30 \\
\hline Red-throated Loon ${ }^{\dagger}$ & Gavia stellata & -4.59 & -10.68 & +1.82 & & & & -9.30 \\
\hline Pacific Loon ${ }^{\dagger}$ & Gavia pacifica & -6.01 & -9.88 & -1.88 & -4.50 & -11.93 & +4.81 & -6.30 \\
\hline Common Loon & Gavia immer & -2.96 & -4.97 & -0.90 & +2.22 & -1.49 & +6.29 & -2.80 \\
\hline Pelagic Cormorant $^{\dagger}$ & Phalacrocorax pelagicus & +0.80 & -4.02 & +6.61 & +3.46 & -2.57 & +8.87 & +1.80 \\
\hline Double-crested Cormorant & Phalacrocorax auritus & -1.98 & -5.26 & +2.12 & +1.01 & -7.04 & +9.31 & -0.40 \\
\hline Great Blue Heron & Ardea herodias & +1.41 & -2.37 & +6.40 & -6.76 & -11.75 & -1.78 & -3.00 \\
\hline Bald Eagle & Haliaeetus leucocephalus & +0.50 & -1.69 & +2.74 & +1.11 & -1.78 & +4.08 & -1.80 \\
\hline Belted Kingfisher & Megaceryle alcyon & 0.00 & -4.69 & +4.50 & -3.92 & -13.06 & +5.44 & \\
\hline
\end{tabular}

${ }^{\dagger}$ Crewe et al. (2012).

${ }^{\dagger}$ Species that occur in globally significant numbers along the British Columbia coast (BirdLife International 2020; Important Bird and Biodiversity Areas in Canada: https://www.ibacanada.com/).

The guild analysis was done using the same framework as previously described for species-specific trends, fitting a separate model for migration distances and dietary categorizations for each region. An additional independent and identically distributed hierarchical term was included to account for random variation in counts among species. The number of routes surveyed within a given year was included as an offset to account for differences in sampling effort. 


\section{RESULTS}

Species-specific trends (annual rates of change) over the past 20 years of the BCCWS are displayed in Table 1 (see also Appendices 2 and 3) for both the Salish Sea and Pacific coast. Trends are considered statistically significant when credibility intervals (CIs) do not overlap zero. Data suggest that most populations are stable (i.e., trends are not significant) in both the Salish Sea (36 of 50 spp.) and Pacific coast (32 of $37 \mathrm{spp}$.) regions. Twelve species displayed significant decline trends in the Salish Sea, whereas two had significant increases (Canada Goose; Ring-necked Duck, Aythya collaris). Along the Pacific coast, only three species displayed significant decline trends (Barrow's Goldeneye, Bucephala islandica; Hooded Merganser, Lophodytes cucullatus; and Great Blue Heron, Ardea herodiasand) and two showed significant increases (Common Murre, Uria aalge and Rednecked Grebe, Podiceps grisegena). Markedly, there was no overlap in the species displaying significant trends between the two study regions.

Guild-specific trends indicate that communities of overwintering waterbirds occupying the Salish Sea are doing significantly less well than those residing along the outer Pacific coast, almost irrespective of dietary specialization or migration distance (Fig. 2). Specifically, all dietary guilds in the Salish Sea, except for herbivores, experienced significant negative trends in abundance from 1999-2019. The steepest declines were in benthivores $(\% / \mathrm{yr}$ : -4.02; CI: $-5.92,-2.18)$ and long-distance migrants $(-4.02$; $-5.92,-2.18)$. In contrast, waterbird guilds along the outer Pacific coast experienced significant increases, apart from benthivores $(2.22 ;-0.40,4.81)$ and omnivores $(-1.29 ;-5.07,2.22)$, whose trends were stable.

Fig. 2. Abundance trends of waterbirds with similar dietary requirements (left panel) and migration strategies (right panel) surveyed from 1999-2019 in the Salish Sea (grey) and outer coastal regions of the Pacific Ocean (black), British Columbia, Canada. Guilds are defined on the y-axis, with migration types comprising long-distance migrants (LDM), short-distance migrants (SMD), and local breeders (Local). Annual percent change and credibility intervals (CI) are displayed on the $\mathrm{x}$-axis. A statistically significant annual trend is implied when upper and lower CIs do not overlap zero (dashed vertical line).

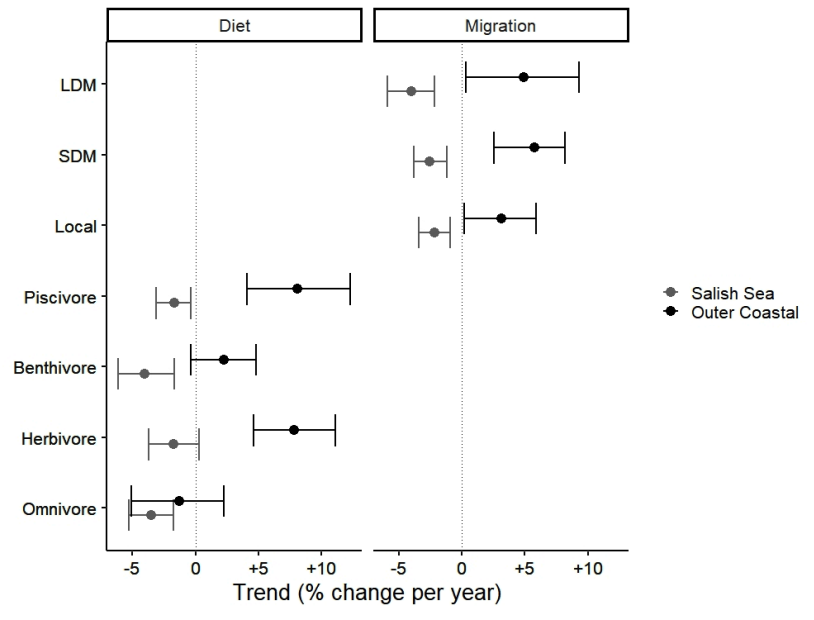

\section{DISCUSSION}

Our results highlight several themes, including species-specific trends of importance to management agencies, 12-yr vs. 20-yr trajectory comparisons within the Canadian Salish Sea, and regional differences in guild-specific abundance patterns, which can better inform future targeted research and conservation initiatives.

\section{Species-specific trends}

Eight taxa maintained significant negative abundance trajectories in the Canadian Salish Sea over the last 20 years (i.e., declining trends reported by Crewe et al. 2012 continued): Scaup spp., White-winged Scoter (Melanitta deglandi), Black Scoter (Melanitta americana), Long-tailed Duck (Clangula hyemalis), Western Grebe (Aechmophorus occidentalis), Dunlin (Calidris alpina), Common Loon (Gavia immer), and Pacific Loon (Gavia pacifica). All of these species are longer distance migrants and upper trophic-level feeders (i.e., piscivorous or benthivorous), except Scaup spp. (omnivorous). Conversely, along the outer Pacific coast, all these species demonstrated stable trajectories. Four additional species in the Salish Sea, which showed stable trends from 1999-2011 (Crewe et al. 2012), demonstrated significant negative trends over the 20-year period: Black Turnstone (Arenaria melanocephala), Surf Scoter (Melanitta perspicillata), Mew Gull (Larus californicus), and Trumpeter Swan (Cygnus buccinator). Each of these taxa are longer distance migrants, except for Trumpeter Swan, and two are benthivorous (Appendix 1). Similarly, none of these taxa demonstrated declines along the outer Pacific coast. Species that demonstrated significant increases in abundance include overwintering populations of Canada Goose and Ring-necked Duck (Aythya collaris) within the Salish Sea (herbivorous and omnivorous, respectively), and Red-necked Grebe (Podiceps grisegena) and Common Murre (Uria aalge) along the outer Pacific coast (both piscivorous). These species are all local breeders or short-distance migrants. In summary, 7 of the 12 negatively trending taxa are benthivorous on their Salish Sea wintering grounds; Common Loon (piscivorous) and Scaup spp. (omnivorous) also feed in the benthic environment in winter (Evers et al. 2020, Kessel et al. 2020). The guild-specific analysis further corroborates the observed species-specific trends found in benthivores in the Salish Sea (Fig. 2). Notwithstanding the fact that many of the benthivorous taxa show declining trends in other parts of their continental and global ranges (Billerman et al. 2020, IUCN 2020), these results suggest that benthic habitat quality in the Salish Sea may deserve further targeted research attention (see Discussion: Guild-specific trends). The only two species to show increases in the Salish Sea were a lower abundance generalist (omnivorous) and a population augmented by previous introductions (Canada Goose; e.g., Isaac-Renton et al. 2010). The piscivore guild has previously been shown to be at highest risk of decline within the Salish Sea, linked to declines in forage fish (Vilchis et al. 2015), so it is interesting to note the increases in these two piscivores along the Pacific coast.

Comparison of our 20-year Salish Sea results with those from Crewe et al. (2012) also show some notable positive differences in species-specific abundance trends, which can be expected given that waterbird populations fluctuate quite widely over decadal time frames (e.g., Wilkins and Otto 2003). Ten of twenty species 
previously showing significant declines showed stable 20-yr trends, which could be indicative of population stabilization or growth since the previous analysis (Appendices 1-3). These species include globally important populations of Harlequin Duck (Histrionicus histrionicus), Surfbird (Calidris virgata), Glaucous-winged Gull (Larus glaucescens), Bonaparte's Gull (Chroicocephalus philadelphia), and Red-throated Loon (Gavia stellata; BirdLife International, global IBA criteria: http:// datazone.birdlife.org/site/ibacritglob). These inter-decadal trend comparisons can be informative to Canada's federal 2002 Species at Risk Act process. Specifically, BCCWS data can be used to inform both the listing process and recovery strategy evaluation. For example, Horned Grebe (Podiceps auratus) was listed federally as a species of Special Concern based on evidence of a $14 \%$ population decline in the previous three generations (COSEWIC 2009), including a declining trend in numbers wintering in the Salish Sea. Our results show that since 2011, the numbers have stabilized or possibly increased. Great Blue Heron (Ardea herodias fannini), also a taxon of Special Concern (COSEWIC 2008), experienced abundance stabilization in the Salish Sea since 2011, compared to a significant declining trend noted between 1999 and 2011 (Crewe et al. 2012). However, along the Pacific coast, this subspecies had a 20-yr declining trend, which suggests that differential pressures affect this species within the Canadian Salish Sea and along the Pacific coast. The BCCWS is considered to have the most robust data for tracking abundance trends in this taxon because of the survey's standardized data collection procedures and robust statistical design (COSEWIC 2008).

Twenty-two species sampled by this survey occur in globally significant numbers along the BC coast (BirdLife International, global IBA criteria: http://datazone.birdlife.org/site/ibacritglob; Table 1); seven of these species experienced 20-yr declines in the Salish Sea, and just one, Red-necked Grebe (Podiceps grisegena), a piscivore, showed an increasing trend on the Pacific coast only. Several of these abundance trends are noteworthy. Declining sea ducks of global significance (e.g., Surf Scoter, White-winged Scoter) are part of the benthivore community considered above. A significant decline in Trumpeter Swan in the Salish Sea (-8.24; $-12.01,-4.40)$ differs from regional trends reported elsewhere, which have noted abundance gains in recent decades (e.g., the Pacific Coast population increased 5.5\%/yr from 1968-2005 and $1.5 \% / y r$ from 2005-2010; Northwest Swan Conservation Association: https://nwswans.org/trumpeter-swans/). The BCCWS is not well designed to sample this swan (Crewe et al. 2012), which uses southern coastal agricultural lands for feeding by day and nearshore waters for roosting. However, these results may indicate a change in trend trajectory in the Canadian Salish Sea after a period of conservation-driven increase and stabilization noted elsewhere (Rees et al. 2019). Continuing loss of winter habitat is identified as a major threat to this species (Trumpeter Swam Society, Pacific coast population: https://www.trumpeterswansociety. org/what-we-do/your-society-at-work/pacific-coast-population.html) as agricultural land use shifts toward more greenhouse and berry crops instead of field crops that provide wintering waterfowl habitat (British Columbia Ministry of Agriculture 2017). The significant decline of Dunlin $(-9.70 ;-13.06,-6.01)$ wintering in the Salish Sea flags a potential conservation issue for local management agencies given that up to $20 \%$ of the Pacific Dunlin
(Calidris alpina pacifica) population winters here (Morrison et al. 2006; Important Bird and Biodiversity Areas in Canada: https:// www.ibacanada.com/). Dunlin (all subspecies) is also identified as a high priority candidate species for assessment by the Committee on the Status of Endangered Wildlife in Canada (COSEWIC), which comprises taxa not yet assessed but where new information suggests they may be at risk of extinction or extirpation (COSEWIC 2020). Black Turnstone, a rocky shore specialist (benthivorous), and Pacific Loon (piscivorous) both showed 20-yr declines in the Salish Sea but stable trends on the outer Pacific coast, contributing to the contrasting pattern between benthic feeders and piscivores on inner and outer coasts. One further taxon to draw attention to is Thayer's Gull (Larus glaucoides thayeri); a large proportion of the global population of this Canadian Arctic breeder winters in the Salish Sea and showed a narrowly nonsignificant declining trend, after both 12 years (Crewe et al. 2012) and 20 years (this study).

Although species-specific trends are informative and, in some instances, likely represent true trends in total population abundance, it is inherently difficult to interpret local changes in the abundance of longer distance migratory waterbirds. This difficulty is in part because local counts do not constitute an exhaustive inventory of the population, nor do they cover the species' entire range. Specifically, abundance trends in one part of a species' range cannot discern if local fluctuations are driven by shifting distributions or changing population numbers (Hyrenbach and Veit 2003). For example, the decline in Western Grebe in the Salish Sea is ongoing but is explained at least partly by a southward nonbreeding range shift of nearly $900 \mathrm{~km}$ during the past three decades (Wilson et al. 2013). To discern better if trends are a result of range-wide population change or redistribution, the Migratory Shorebird Project was established in 2013 to sample nonbreeding populations of shorebirds along the Pacific Coast of the Americas (Reiter et al. 2020). This hemispheric, hypothesis-driven monitoring framework, to which the BCCWS is a contributing partner, will provide the context to better assess local causes of declines in shorebird species of conservation concern.

\section{Guild-specific trends}

Within the Salish Sea, our results support the prediction that abundance declines are more prevalent in higher trophic-level feeders, with significant declines experienced by all guilds except herbivores (Fig. 2). Our findings align with those of Vilchis et al. (2015) for piscivores and guilds without local breeding populations and, for the first time, highlight benthivores as the guild showing steepest 20-yr declines. Putative mechanisms behind these changes in abundance could include: redistribution in response to prey (demonstrated for Western Grebe; Wilson et al. 2013), redistribution in response to predators (e.g., Middleton et al. [2018] found that dive-feeding birds in the Salish Sea, including scoters, moved away from shore in response to the threat from Bald Eagle Haliaeetus leucogaster), factors operating in other parts of the ranges of longer distance migrants (e.g., climate-driven changes in aquatic invertebrate prey on boreal or arctic breeding grounds; e.g., Corcoran et al. 2009, Arzel et al. 2020), and changes to benthic and epibenthic food sources in the Salish Sea. Duck species that have benefited from ongoing conservation investment in $>80,000 \mathrm{~km}^{2}$ of wetlands and adjacent 
lands in Canada, under the North American Waterfowl Management Plan (NABCI-Canada 2019), showed stable or increasing species-specific trends in the Salish Sea, including American Wigeon (Mareca americana), Northern Pintail (Anas acuta), and Green-winged Teal (Anas crecca). At the guild level, these herbivores were the only group that showed a (narrowly) stable trend (Fig. 2).

When combined, results from the Salish Sea and Pacific coasts did not lend support to our guild-level hypotheses. Specifically, there was no evidence that abundance declines were more prevalent in higher trophic-level feeders along the Pacific coast, where piscivores $(8.11 ; 4.08,12.30)$ experienced significant abundance gains (Fig. 2). The prediction that longer distance migrants would be more susceptible to declines than local breeders was also unsupported; all three guilds (local breeders, short-distance and long-distance migrants) experienced abundance gains along the Pacific coast (Fig. 2). These guildspecific results provide evidence of consistently contrasting patterns within and outside the Salish Sea, suggesting that differential pressures may be causing overall loss of wintering waterbirds within, or abundance shifts away from, the Salish Sea, a pattern already demonstrated for Western Grebe (Wilson et al. 2013). This finding should be of particular interest to agencies responsible for the bird populations and their habitats in the Salish Sea, specifically Environment and Climate Change Canada, Fisheries and Oceans Canada, the Government of British Columbia, the Pacific Birds Habitat and Sea Duck Joint Ventures, and Indigenous Governments. Canadian agencies share responsibility for management of the Salish Sea with agencies in Puget Sound, Washington, USA, where one of the largest ecosystem restoration programs in the United States is underway (Puget Sound Partnership 2018). The results of seven years of citizen science data from the Puget Sound Seabird Survey, coordinated by the Seattle Audubon Society, were more encouraging than ours. Ward et al. (2015) showed evidence of local increases in 14 of 18 species in Puget Sound, especially those with local breeding populations, and some commonalities in declining species with our 20-yr results (e.g., White-winged Scoter, Western Grebe), raising the possibility that localized active restoration is a mechanism to consider in understanding changes in coastal waterbird abundances in other regions of the Salish Sea.

\section{CONCLUSIONS}

Results from this study further demonstrate that citizen science data provide robust insight into regional abundance trends of coastal waterbirds and the commonalities that influence their susceptibility to environmental pressures (Bower 2009, Vilchis et al. 2015). These abundance trends are important for evaluating the status of vulnerable and ecologically significant populations (e.g., COSEWIC, Pacific America's Shorebird Conservation Strategy, Important Bird and Biodiversity Areas), and establishing baseline statistics against which policy changes can be evaluated (e.g., oil spill monitoring; O'Hara et al. 2009). Longterm citizen science monitoring of coastal ecosystems provides a foundation from which to tease apart whether local population fluctuations are a result of true changing abundance or shifts in species distributions over time (Vilchis et al. 2015, Reiter et al. 2020) and to resolve the mechanisms responsible (e.g., Bianchini et al. 2020). Organisms living in the Salish Sea are exposed to differential environmental and human-induced pressures than those along the outer Pacific coast. For example, nutrient pollution from rivers, nonpoint source runoff, and wastewater sources have been recognized as primary threats to the ecological health of the inner waters of the Salish Sea (Khangaonkar et al. 2019). The effects of nutrient pollution on coastal ecosystems are exacerbated when coupled with projected future climate stressors, the negative effects of chemical pollution from industry and municipalities, oil spills, invasive species, and increased pressures from shipping, fishing, recreation, and shoreline development, all of which are likely to affect the Salish Sea to a greater extent than the outer coastal waters of the Pacific Ocean (e.g., Stocks and Vandeborne 2017). Collaborative research combining the BCCWS data set with compatible waterbird surveys (e.g., Puget Sound Seabird Survey, Seattle Audubon: https://www. seattleaudubon.org/sas/About/Science/CitizenScience/

PugetSoundSeabirdSurvey.aspx), monitoring levels of food resources (e.g., plankton food web [Costalago et al. 2020], benthic surveys [Ranasinghe et al. 2013]), monitoring of rocky intertidal communities (e.g., Multi-agency Rocky Intertidal Network, Washington Salish Sea sites: https://marine.ucsc.edu/sites/sitesregion/sites-region-wa.html), and integrated stakeholder participation (Bayard et al. 2019) would enable the necessary hypothesis testing to improve the understanding of waterbird abundance trends and the conservation actions needed in the Salish Sea and along the Pacific coast.

Responses to this article can be read online at: https://www.ace-eco.org/issues/responses.php/1711

\section{Acknowledgments:}

The British Columbia Coastal Waterbird Survey was conceived by a group of scientists, local naturalists, and conservation planners, and initiated in 1999 by Birds Canada. The survey is maintained annually through funding from the Canadian Wildlife Service, a branch of Environment and Climate Change Canada; additional support has been provided by the Vancouver Foundation, BC Waterfowl Society, Public Conservation Assistance Fund of the Habitat Conservation Trust Foundation, TD Friends of the Environment Fund, The Port of Vancouver, and BC Field Ornithologists. We thank the 1600 volunteers that have collected data over the past 20 years who made this analysis possible. Two anonymous reviewers provided valuable input, which improved the clarity of our manuscript.

\section{LITERATURE CITED}

Ainley, D. G., and K. D. Hyrenbach. 2010. Top-down and bottom-up factors affecting seabird population trends in the California current system (1985-2006). Progress in Oceanography 84(3-4):242-254. https://doi.org/10.1016/j.pocean.2009.10.001

Anderson, E. M., J. L. Bower, D. R. Nysewander, J. R. Evenson, and J. R. Lovvorn. 2009. Changes in avifaunal abundance in a heavily used wintering and migration site in Puget Sound, Washington, During 1966-2007. Marine Ornithology 37:19-27. [online] URL: https://www.marineornithology.org/PDF/37_1/37_1_19-27. pdf 
Arzel, C., P. Nummi, L. Arvola, H. Pöysä, A. Davranche, M. Rask, M. Olin, S. Holopainen, R. Viitala, E. Einola, and S. Manninen-Johansen. 2020. Invertebrates are declining in boreal aquatic habitat: the effect of brownification? Science of the Total Environment 724:138199. https://doi.org/10.1016/j.scitotenv.2020.138199

Badzinski, S. S., R. J. Cannings, T. E. Armenta, J. Komaromi, and P. J. A. Davidson. 2006. The British Columbia coastal waterbird survey: an evaluation of survey power and species trends after five years of monitoring. Technical Report Series 455. Canadian Wildlife Service, Pacific and Yukon Region, Delta, Canada. [online] URL: http://publications.gc.ca/collections/collection_2018/ ecce/cw69-5/CW69-5-455-eng.pdf

Ballance, L. T., R. L. Pitman, and S. B. Reilly. 1997. Seabird community structure along a productivity gradient: importance of competition and energetic constraint. Ecology 78 (5):1502-1518. https://doi.org/10.1890/0012-9658(1997)078[1502: SCSAAP]2.0.CO;2

Bayard, T., G. Slater, K. Spragens, and A. Summers. 2019. Recommendations for a Puget Sound estuary avian monitoring strategy. A synthesis report to the Puget Sound Ecosystem Monitoring Program and Puget Sound Partnership. Audubon, Tacoma, Washington, USA. [online] URL: https://wa.audubon. org/sites/default/files/static_pages/attachments/bayard_et_al._2019.

recommendations_avian_monitoring_strategy_puget_sound_estuaries. pdf

BC Stats. 2020. British Columbia - population estimates. Government of British Columbia, Victoria, Canada. [online] URL: https://bcstats.shinyapps.io/popApp/

Bianchini, K., D. C. Tozer, R. Alvo, S. P. Bhavsar, and M. L. Mallory. 2020. Drivers of declines in common loon (Gavia immer) productivity in Ontario, Canada. Science of the Total Environment 738:139724. https://doi.org/10.1016/j.scitotenv.2020.139724

Billerman, S. M., B. K. Keeney, P. G. Rodewald, and T. S. Schulenberg, editors. 2020. Birds of the world. Cornell Laboratory of Ornithology, Ithaca, New York, USA. [online] URL: https:// doi.org/10.2173/bow

Birds Canada. 2013. BC coastal waterbird survey: training module for volunteers. Birds Canada, Port Rowan, Canada. [online] URL: https://www.birdscanada.org/wp-content/uploads/2020/02/BCCWSTraining-Module.pdf

Birds Canada. 2018. BC coastal waterbird survey protocol: instructions for participants. Birds Canada, Port Rowan, Canada. [online] URL: https://www.birdscanada.org/wp-content/uploads/2020/02/ BCCWS-Protocol.pdf

Bower, J. L. 2009. Changes in marine bird abundance in the Salish Sea: 1975 to 2007. Marine Ornithology 37:9-17. [online] URL: http://www.marineornithology.org/PDF/37_1/37_1_9-17.pdf

British Columbia Ministry of Agriculture. 2017. Agriculture in brief: Fraser Valley regional district 2016. British Columbia Ministry of Agriculture, Victoria, Canada. [online] URL: https:// www2.gov.bc.ca/assets/gov/farming-natural-resources-and-industry/ agriculture-and-seafood/statistics/census/census-2016/ aginbrief_2016_fraser_valley.pdf
Burger, J., and M. Gochfeld. 1991. Human distance and birds: tolerance and response distances of resident and migrant species in India. Environmental Conservation 18(2):158-165. https://doi. org/10.1017/S0376892900021743

Committee on the Status of Endangered Wildlife in Canada (COSEWIC). 2008. COSEWIC assessment and update status report on the Great Blue Heron Ardea herodias fannini, fannini subspecies, in Canada. COSEWIC, Ottawa, Canada. [online] URL: https://www.sararegistry.gc.ca/virtual_sara/files/cosewic/ sr_great_blue_heron_0808_e.pdf

Committee on the Status of Endangered Wildlife in Canada (COSEWIC). 2009. COSEWIC assessment and status report on the Horned Grebe Podiceps auritus, Western population and Magdalen Islands population, in Canada. COSEWIC, Ottawa, Canada. [online] URL: https://www.sararegistry.gc.ca/virtual_sara/ files/cosewic/sr_horned_grebe_0809_e.pdf

Committee on the Status of Endangered Wildlife in Canada (COSEWIC). 2020. COSEWIC candidate wildlife species. COSEWIC, Ottawa, Canada. [online] URL: http://www.cosewic. ca/index.php/en-ca/reports/candidate-wildlife-species

Corcoran, R. M., J. R. Lovvorn, and P. J. Heglund. 2009. Longterm change in limnology and invertebrates in Alaskan boreal wetlands. Hydrobiologia 620:77-89. https://doi.org/10.1007/ s10750-008-9616-5

Costalago, D., I. Forster, N. Nemcek, C. Neville, R. I. Perry, K. Young, B. P. V. Hunt. 2020. Seasonal and spatial dynamics of the planktonic trophic biomarkers in the Strait of Georgia (northeast Pacific) and implications for fish. Scientific Reports 10:8517. https://doi.org/10.1038/s41598-020-65557-1

Crewe, T., K. Barry, P. Davidson, and D. Lepage. 2012. Coastal waterbird population trends in the Strait of Georgia 1999-2011: results from the first 12 years of the British Columbia coastal waterbird survey. British Columbia Birds 22:8-39. [online] URL: https://bcbirds.bcfo.ca/volume-22-3/

Davidson, P. J. A., R. J. Cannings, A. R. Couturier, D. Lepage, and C. M. Di Corrado, editors. 2015. Atlas of the breeding birds of British Columbia, 2008-2012. Bird Studies Canada, Delta, Canada. [online] URL: http://www.birdatlas.bc.ca/

Evers, D. C., J. D. Paruk, J. W. McIntyre, and J. F. Barr. 2020. Common Loon (Gavia immer), version 1.0. In S. M. Billerman, editor. Birds of the world. Cornell Laboratory of Ornithology, Ithaca, New York, USA. [online] URL: https://doi.org/10.2173/ bow.comloo. 01

Gamfeldt, L., J. S. Lefcheck, J. E. K. Byrnes, B. J. Cardinale, J. E. Duffy, and J. N. Griffin. 2015. Marine biodiversity and ecosystem functioning: What's known and what's next? Oikos 124 (3):252-265. https://doi.org/10.1111/oik.01549

Gaydos, J. K., L. Dierauf, G. Kirby, D. Brosnan, K. Gilardi, and G. E. Davis. 2008. Top 10 principles for designing healthy coastal ecosystems like the Salish Sea. EcoHealth 5:460. https://doi. org/10.1007/s10393-009-0209-1

Gaydos, J. K., and S. F. Pearson. 2011. Birds and mammals that depend on the Salish Sea: a compilation. Northwestern Naturalist 92(2):79-94. https://doi.org/10.1898/10-04.1 
Harley, C. D. G., A. R. Hughes, K. M. Hultgren, B. G. Miner, C. J. B. Sorte, C. S. Thornber, L. F. Rodriguez, L. Tomanek, and S. L. Williams. 2006. The impacts of climate change in coastal marine systems. Ecology Letters 9(2):228-241. https://doi. org/10.1111/j.1461-0248.2005.00871.X

Held, L., B. Schrödle, and H. Rue. 2010. Posterior and crossvalidatory predictive checks: a comparison of MCMC and INLA. Pages 91-110 in T. Kneib and G. Tutz, editors. Stastical modelling and regression studies: festschrift in honour of Ludwig Fahrmeir. Physica, Heidelberg, Germany. https://doi.org/10.1007/978-3-7908-2413-1_6

Hyrenbach, K. D., and R. R. Veit. 2003. Ocean warming and seabird communities of the southern California Current System (1987-98): response at multiple temporal scales. Deep Sea Research Part II: Topical Studies in Oceanography 50 (14-16):2537-2565. https://doi.org/10.1016/S0967-0645(03)00123-1

International Union for Conservation of Nature (IUCN). 2020. The IUCN Red List of threatened species. Version 2020-2. IUCN, Cambridge, UK. [online] https://www.iucnredlist.org/

Isaac-Renton, M., J. R. Bennett, R. J. Best, and P. Arcese. 2010. Effects of introduced Canada geese (Branta canadensis) on native plant communities of the southern Gulf Islands, British Columbia. Écoscience 17(4):394-399. https://doi.org/10.2980/17-4-3332

Kennish, M. J. 2002. Environmental threats and environmental future of estuaries. Environmental Conservation 29(1):78-107. https://doi.org/10.1017/S0376892902000061

Kessel, B., D. A. Rocque, and J. S. Barclay. 2020. Greater Scaup (Aythya marila), version 1.0. In S. M. Billerman, editor. Birds of the world. Cornell Laboratory of Ornithology, Ithaca, New York, USA. https://doi.org/10.2173/bow.gresca.01

Khangaonkar, T., A. Nugraha, W. Xu, and K. Balaguru. 2019. Salish Sea response to global climate change, sea level rise, and future nutrient loads. Journal of Geophysical Research: Oceans 124(6):3876-3904. https://doi.org/10.1029/2018JC014670

Marks, J. S., and R. L. Redmond. 1994. Migration of bristlethighed curlews on Laysan Island: timing, behavior and estimated flight range. Condor 96(2):316-330. https://doi.org/10.2307/1369317

Middleton, H. A., R. W. Butler, and P. Davidson. 2018. Waterbirds alter their distribution and behavior in the presence of bald eagles (Haliaeetus leucocephalus). Northwestern Naturalist 99(1):21-30. https://doi.org/10.1898/nwn16-21.1

Möllmann, C., and R. Diekmann. 2012. Marine ecosystem regime shifts induced by climate and overfishing: a review for the Northern Hemisphere. Advances in Ecological Research 47:303-347. https://doi.org/10.1016/B978-0-12-398315-2.00004-1

Moore, J. K., W. Fu, F. Primeau, G. L. Britten, K. Lindsay, M. Long, S. C. Doney, N. Mahowald, F. Hoffman, and J. T. Randerson. 2018. Sustained climate warming drives declining marine biological productivity. Science 359:1139-1143. https:// doi.org/10.1126/science.aao6379

Morrison, R. I. G., B. J. McCaffery, R. E. Gill, S. K. Skagen, S. L. Jones, G. W. Page, C. L. Gratto-Trevor, and B. A. Andres. 2006. Population estimates of North American shorebirds, 2006. Wader
Study Group Bulletin 111:67-85. [online] URL: https://www. waderstudygroup.org/article/3068/

North American Bird Conservation Initiative Canada (NABCICanada). 2019. The state of Canada's birds: 2019. NABCICanada, Gatineau, Canada. [online] URL: http://nabci.net/wpcontent/uploads/2019-State-of-Canadas-Birds-1.pdf

O'Hara, P. D., P. Davidson, and A. E. Burger. 2009. Aerial surveillance and oil spill impacts based on beached bird survey data collected in southern British Columbia. Marine Ornithology 37:61-65. [online] URL: http://www.marineornithology.org/ PDF/37_1/37_1_61-65.pdf

Puget Sound Partnership. 2018. The 2018-2022 action agenda for Puget Sound. Puget Sound Partnership, Olympia, Washington, USA. [online] URL: https://pspwa.app.box.com/s/ osxaeqg19fevxu5n3k8xnjytzkwol512

R Core Team. 2014. R: a language and environment for statistical computing. R Foundation for Statistical Computing, Vienna, Austria.

Ranasinghe, J. A., E. D. Stein, M. R. Frazier, and D. J. Gillett. 2013. Development of Puget Sound benthic indicators: report to the Washington State Department of Ecology. SCCWRP Technical Report 755. Washington State Department of Ecology Publication 13-03-035. Washington State Department of Ecology, Olympia, Washington, USA. [online] URL: https:// fortress.wa.gov/ecy/publications/documents/1303035.pdf

Rees, E. C., L. Cao, P. Clausen, J. T. Coleman, J. Cornely, O. Einarsson, C. R. Ely, R. T. Kingford, M. Ma, C. D. Mitchell, S. Nagy, T. Shindad, J. Snyder, D. V. Solovyeva, W. Tijsen, Y. A. Vilina, R. Włodarczyk, and K. Brides. 2019. Conservation status of the world's swan population, Cygnus sp. and Coscoroba sp.: a review of current trends and gaps in knowledge. Wildfowl 5:35-72. [online] URL: https://wildfowl.wwt.org.uk/index.php/wildfowl/ article/view/2705

Reiter, M. E., E. Palacios, D. Eusse-Gonzalez, R. Johnston, P. Davidson, D. W. Bradley, R. Clay, K. M. Strum, J. Chu, B. A. Barbaree, C. M. Hickey, D. B. Lank, M. Drever, R. C. Ydenberg, and R. Butler. 2020. A monitoring framework for assessing threats to nonbreeding shorebirds on the Pacific coast of the Americas. Avain Conservation and Ecology 15(2):7. https://doi.org/10.5751/ ACE-01620-150207

Rue, H., S. Martino, and N. Chopin. 2009. Approximate Bayesian inference for latent Gaussian models by using integrated nested Laplace approximations. Journal of the Royal Statistical Society: Series B 71(2):319-392. https://doi.org/10.1111/j.1467-9868.2008.00700. $\mathrm{x}$

Stocks, A., and K. Vandeborne. 2017. The state of coastal communities in British Columbia. T. Buck Suzuki Environmental Foundation, Victoria, Canada. [online] URL: https:// d3n8a8pro7vhmx.cloudfront.net/tbucksuzuki/pages/158/attachments/ original/1576611259/The_State_of_Coastal_Communities_in_British_Columbia_2017.pdf?1576611259

Thrush, S. F., J. E. Hewitt, V. J. Cummings, P. K. Dayton, M. Cryer, S. J. Turner, G. A. Funnell, R. G. Budd, C. J. Milburn, and M. R. Wilkinson. 1998. Disturbance of the marine benthic habitat by commercial fishing: impacts at the scale of the fishery. 
Vilchis, L. I., C. K. Johnson, J. R. Evenson, S. F. Pearson, K. L. Barry, P. Davidson, M. G. Raphael, and J. K. Gaydos. 2015. Assessing ecological correlates of marine bird declines to inform marine conservation. Conservation Biology 29(1):154-163. https:// doi.org/10.1111/cobi.12378

Ward, E. J., K. N. Marshall, T. Ross, A. Sedgley, T. Hass, S. F. Pearson, G. Joyce, N. J. Hamel, P. J. Hodum, and R. Faucett. 2015. Using citizen-science data to identify local hotspots of seabird occurrence. PeerJ 3:e704. https://doi.org/10.7717/peerj.704

Wilkins, K. A., and M. C. Otto. 2003. Trends in duck breeding populations, 1955-2003. Administrative Report. U.S. Fish and Wildlife Service, Laurel, Maryland, USA. [online] URL: https:// www.fws.gov/migratorybirds/pdf/surveys-and-data/Population-status/ Trends/TrendsinDuckBreedingPopulations03.pdf

Willie, M., D. Esler, W. S. Boyd, T. Bowman, J. Schamber, and J. Thompson. 2020. Annual winter site fidelity of Barrow's Goldeneyes in the Pacific. Journal of Wildlife Management 84 (1):161-171. https://doi.org/10.1002/jwmg.21767

Wilson, S., E. M. Anderson, A. S. G. Wilson, D. F. Bertram, and P. Arcese. 2013. Citizen science reveals an extensive shift in the winter distribution of migratory Western Grebes. Plos One 8(6): e65408. https://doi.org/10.1371/journal.pone.0065408

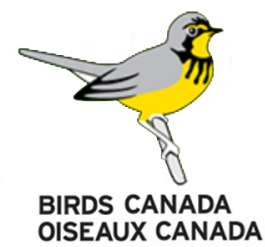


Erratum: In the original publication Appendix 1 was incomplete. This complete appendix was attached to the manuscript on 31 March 2021.

\section{Appendix 1}

Species-specific survey windows (.) were assigned based on local knowledge of the months in the non-breeding season that each species is most prevalent off the coast of British Columbia, Canada. Species were also classified into guilds based on migration distance and dietary specialization following Bower (2009) and Billerman et al. (2020).

Species Name

Brant

Canada Goose

Trumpeter Swan

Gadwall

Eurasian Wigeon

American Wigeon

Mallard

Northern Pintail

Green-winged Teal

Ring-necked Duck

Scaup Spp.

Harlequin Duck

Surf Scoter

White-winged Scoter

Black Scoter

Long-tailed Duck

Bufflehead

Common Goldeneye

Barrow's Goldeneye

Hooded Merganser

Common Merganser

Red-breasted Merganser

Horned Grebe

Red-necked Grebe

Western Grebe

Black Oystercatcher

Black-bellied Plover

Killdeer

Black Turnstone

Surfbird

Dunlin

Greater Yellowlegs

Common Murre

Pigeon Guillemot

Marbled Murrelet

Bonaparte's Gull

Heermann's Gull

Mew Gull

Ring-billed Gull

California Gull

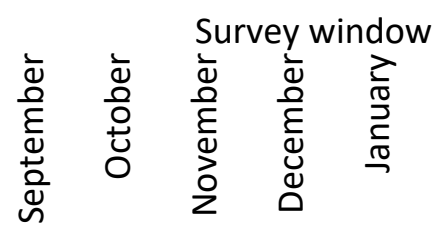

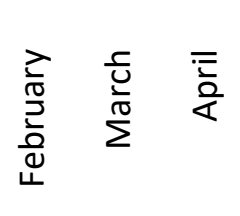

Migration

Long Distance

Local Breeder

Short Distance

Local Breeder

Long Distance

Local Breeder

Local Breeder

Short Distance

Short Distance

Short Distance

Long Distance

Local Breeder

Long Distance

Short Distance

Long Distance

Long Distance

Short Distance

Short Distance

Short Distance

Local Breeder

Local Breeder

Short Distance

Short Distance

Short Distance

Short Distance

Local Breeder

Long Distance

Local Breeder

Long Distance

Long Distance

Long Distance

Short Distance

Local Breeder

Short Distance

Local Breeder

Long Distance

Long Distance

Short Distance

Short Distance

Short Distance
Dietary specialization

Herbivore

Herbivore

Herbivore

Herbivore

Herbivore

Herbivore

Herbivore

Herbivore

Herbivore

Omnivore

Omnivore

Benthivore

Benthivore

Benthivore

Benthivore

Benthivore

Benthivore

Benthivore

Benthivore

Piscivore

Piscivore

Piscivore

Piscivore

Piscivore

Piscivore

Benthivore

Benthivore

Omnivore

Benthivore

Benthivore

Benthivore

Benthivore

Piscivore

Piscivore

Piscivore

Omnivore

Piscivore

Omnivore

Omnivore

Omnivore 
Appendix 1

Species Name

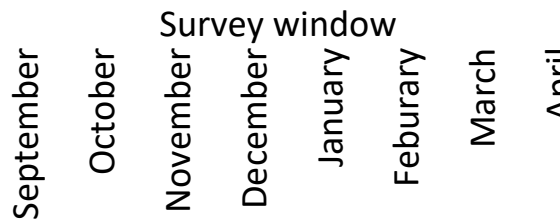

Thayer's Gull

Glaucous-winged Gull

Red-throated Loon

Pacific Loon

Common Loon

Pelagic Cormorant

Double-crested Cormorant

Great Blue Heron

Bald Eagle

Belted Kingfisher

Migration Dietary

distance specilization

Long Distance Omnivore

Local Breeder Omnivore

Short Distance Piscivore

Long Distance Piscivore

Short Distance Piscivore

Local Breeder Piscivore

Local Breeder Piscivore

Local Breeder Omnivore

Local Breeder Omnivore

Local Breeder Piscivore 


\section{Appendix 2}

Twenty-year trends of costal waterbirds residing in the Salish Sea, British Columbia, Canada. The black dots on the graph are estimated indices of annual population size as calculated by the statistical model, with error bars representing the $95 \%$ credible intervals for the annual indices. Annual indices are expressed on a linear scale and represent the average of the predicted number of individual birds detected per day of survey. The black line is a smoothed visualization of the change in annual indices over time. The title of the plot contains the estimated linear trend value expressed as annual percent change per year of mean total count. The lower and upper limits of the 95\% credible interval $(\mathrm{Cl})$ of the trends are shown in parentheses along with the posterior probability of the trend: a value greater than or equal to 0.95 provides additional support for the observed trend. 


\section{Appendix 2}

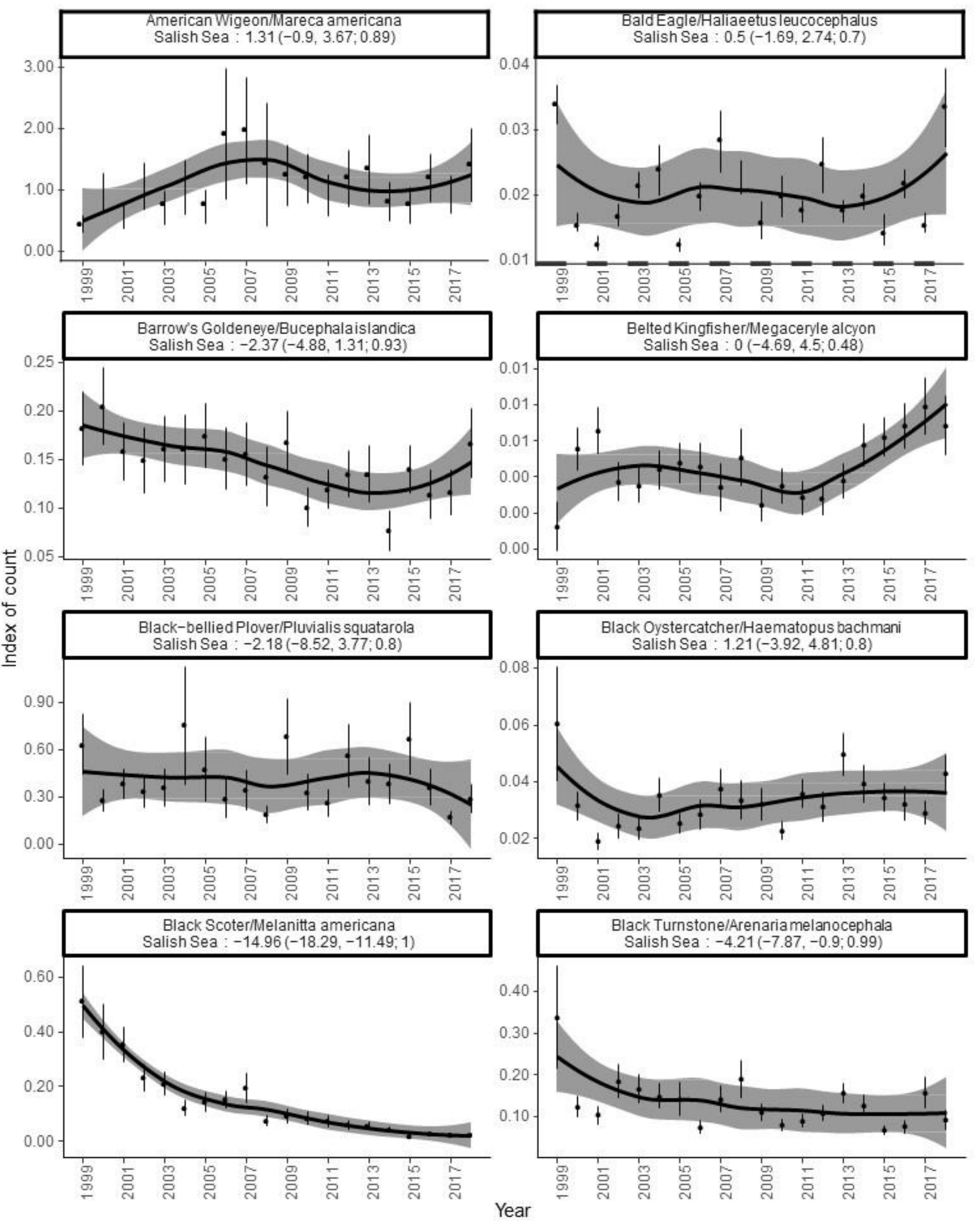




\section{Appendix 2}

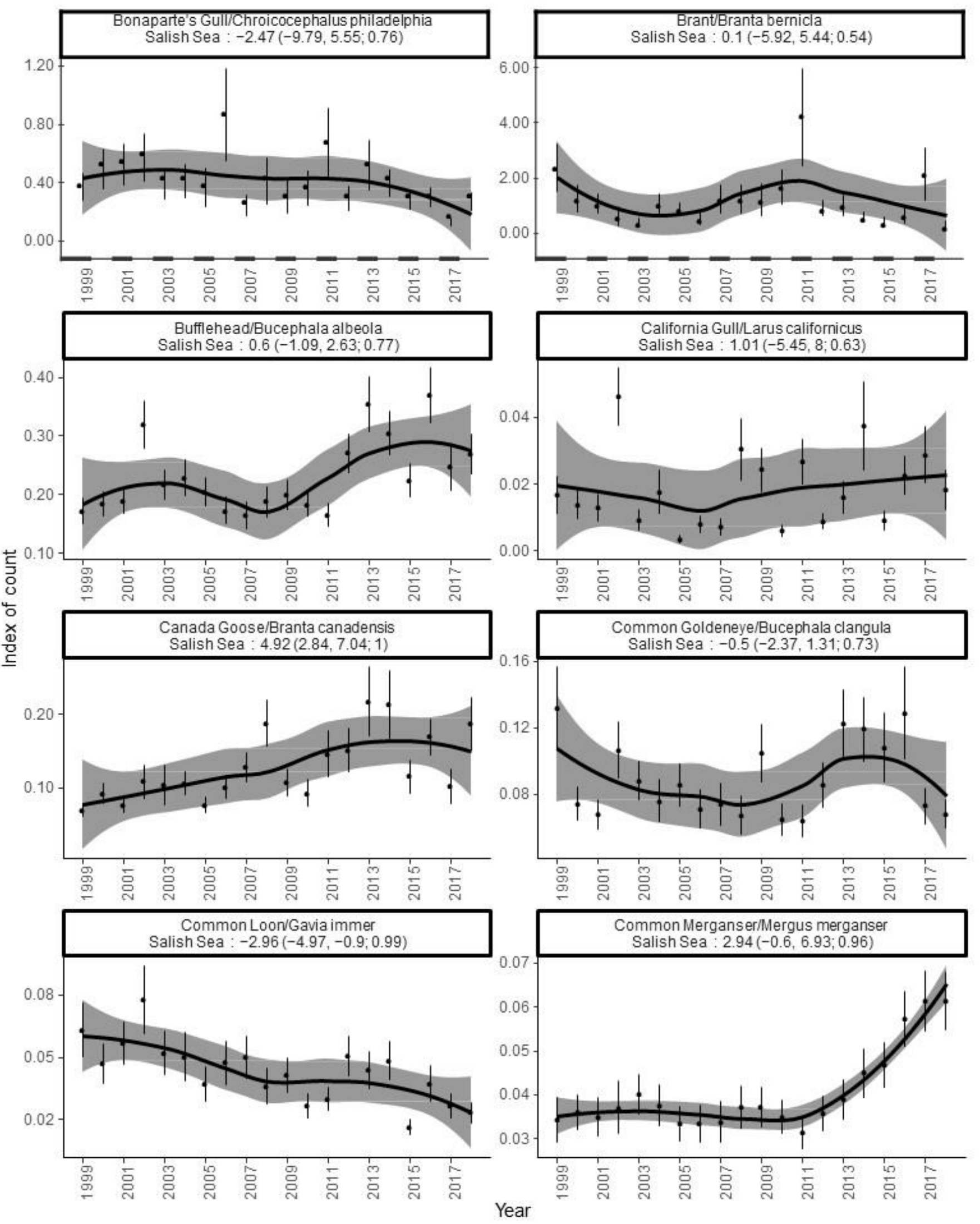




\section{Appendix 2}

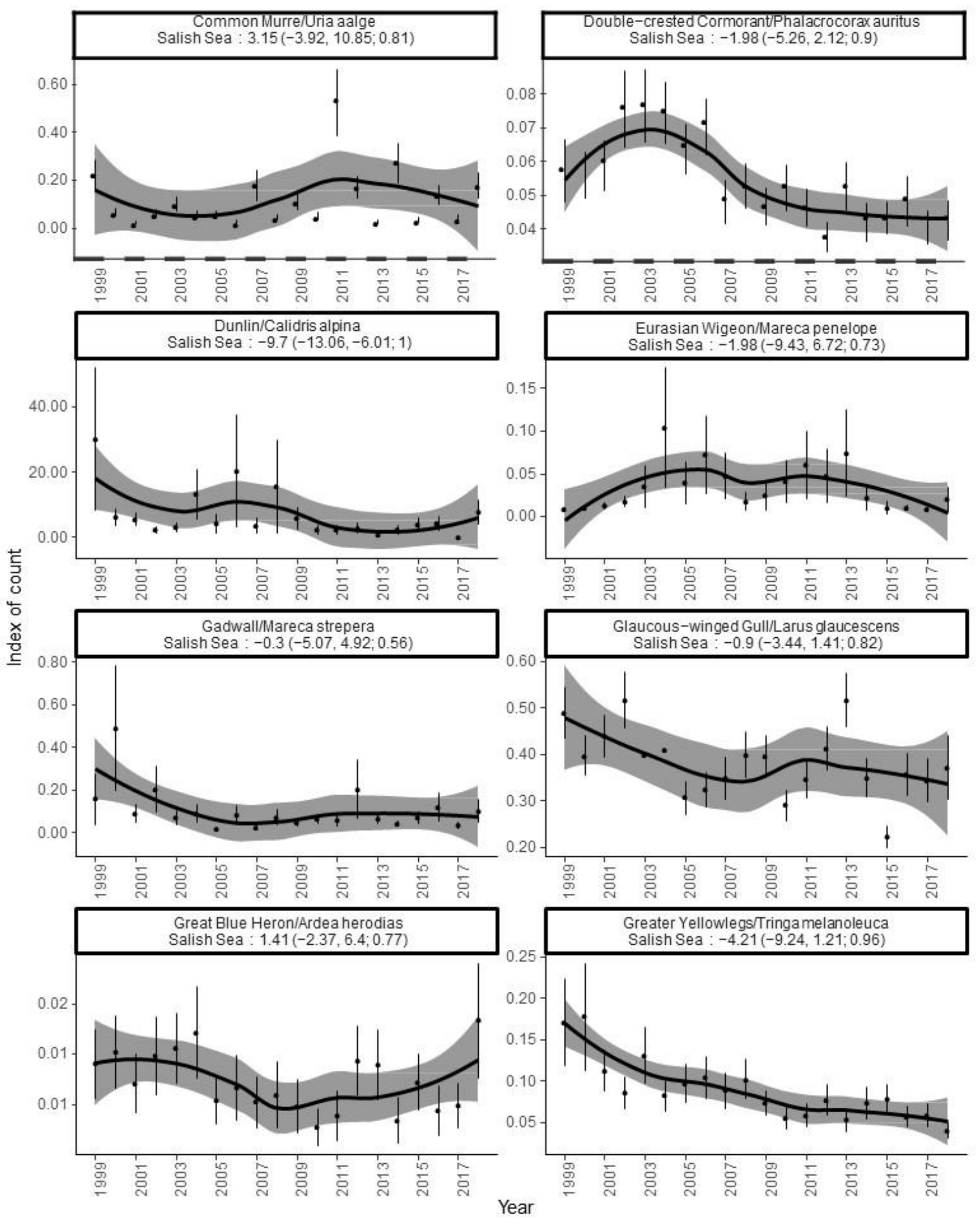




\section{Appendix 2}

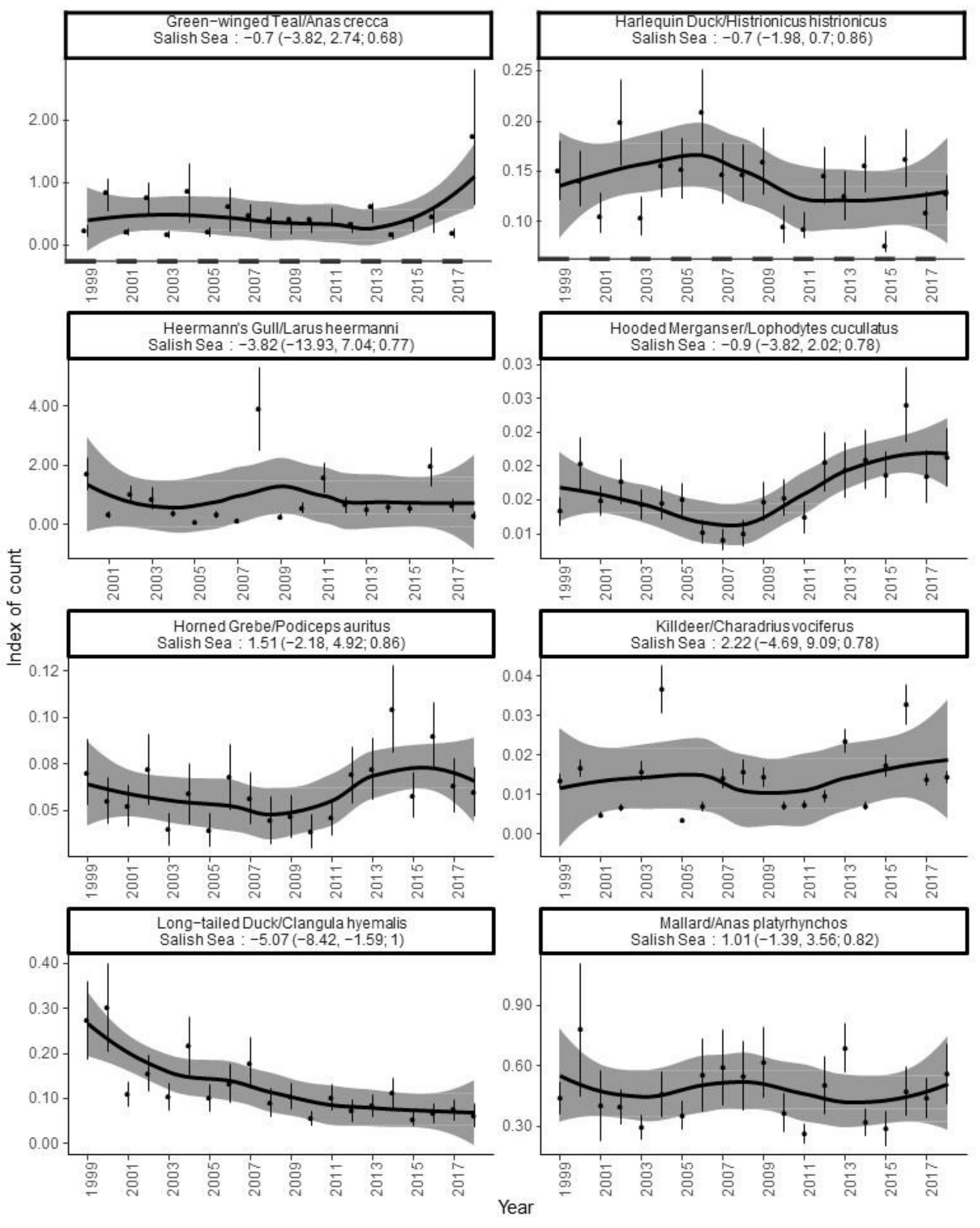




\section{Appendix 2}
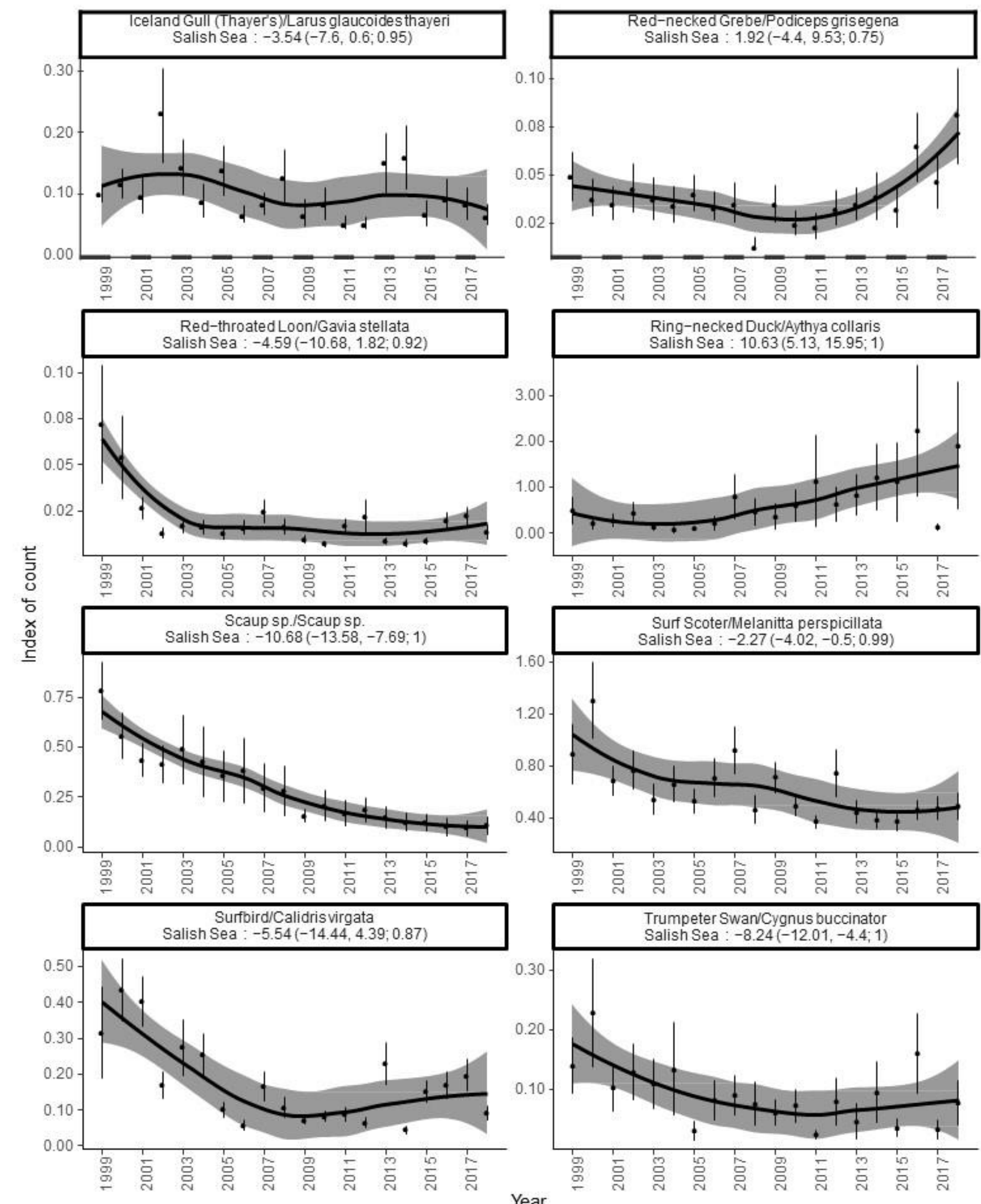

0.30 


\section{Appendix 2}

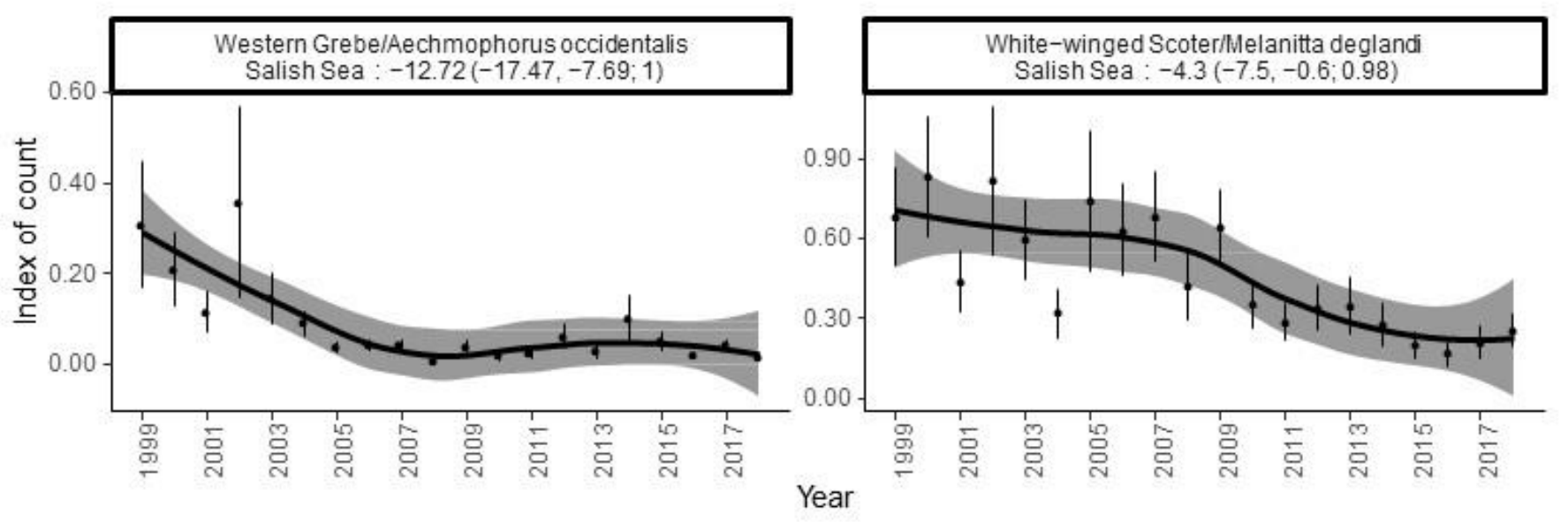




\section{Appendix 3}

Twenty-year trends of costal waterbirds residing in the outer costal waters of the Pacific Ocean, British Columbia, Canada. The black dots on the graph are estimated indices of annual population size as calculated by the statistical model, with error bars representing the $95 \%$ credible intervals for the annual indices. Annual indices are expressed on a linear scale and represent the average of the predicted number of individual birds detected per day of survey. The black line is a smoothed visualization of the change in annual indices over time. The title of the plot contains the estimated linear trend value expressed as annual percent change per year of mean total count. The lower and upper limits of the $95 \%$ credible interval $(\mathrm{Cl})$ of the trends are shown in parentheses along with the posterior probability of the trend: a value greater than or equal to 0.95 provides additional support for the observed trend. 


\section{Appendix 3}

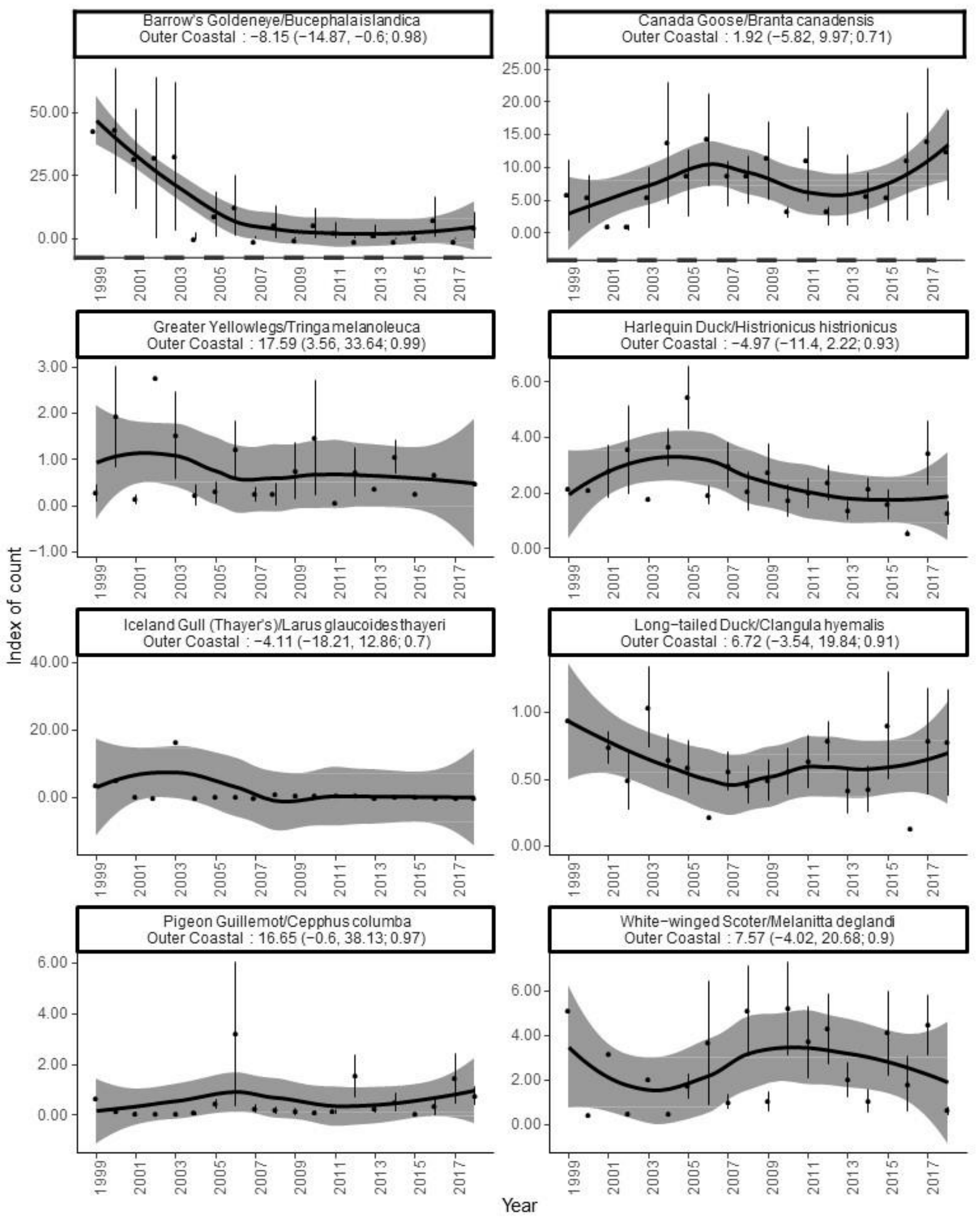




\section{Appendix 3}

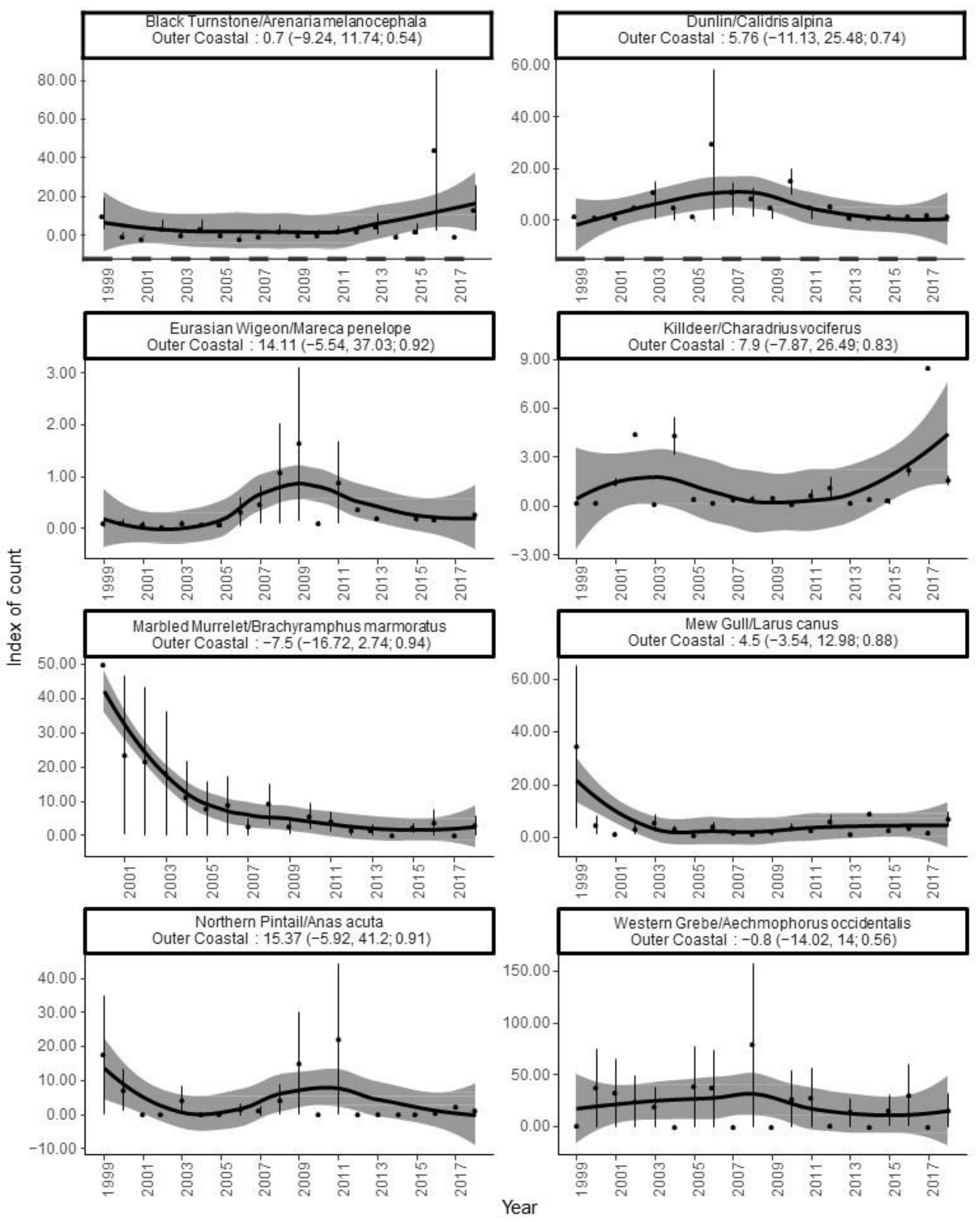




\section{Appendix 3}

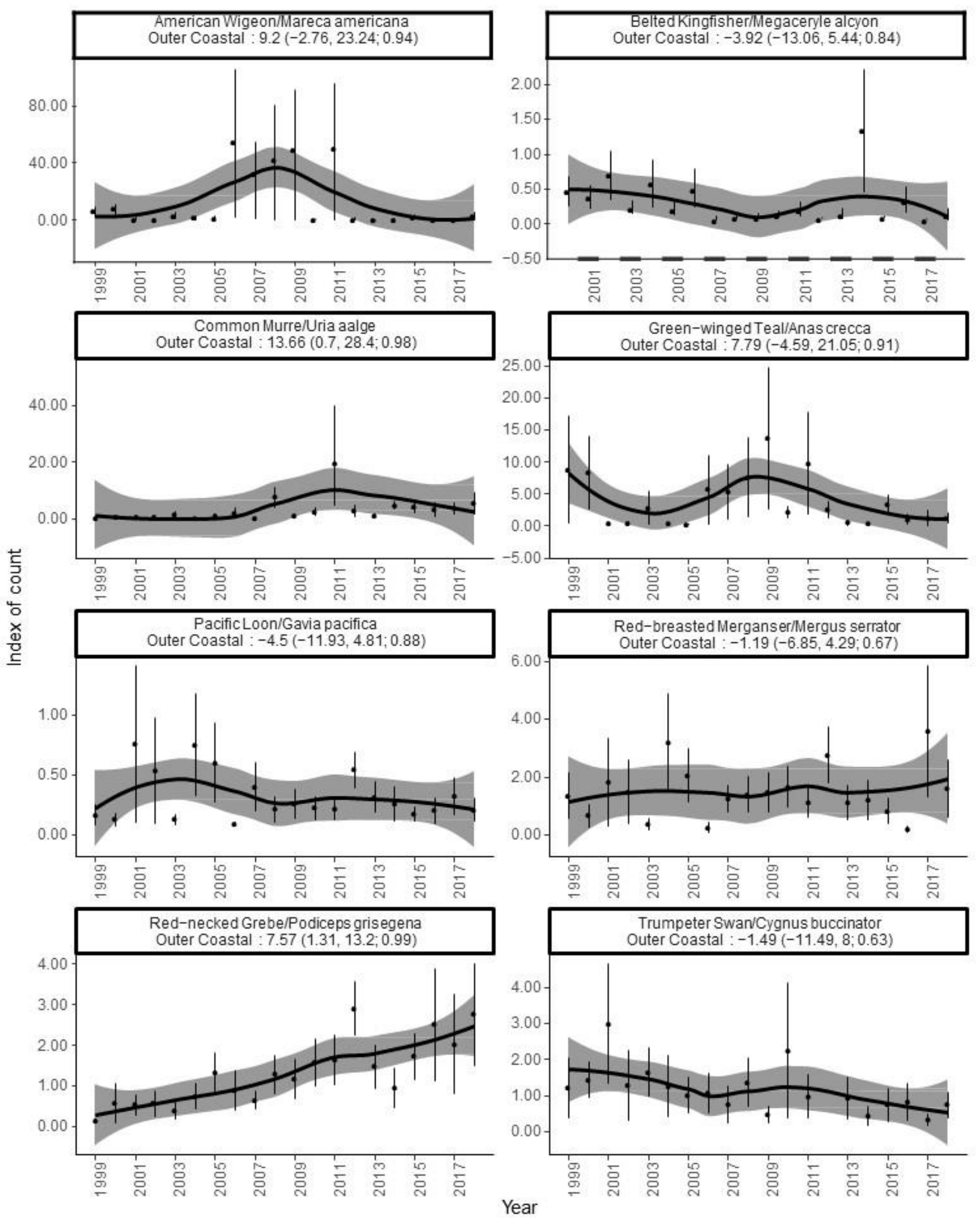




\section{Appendix 3}

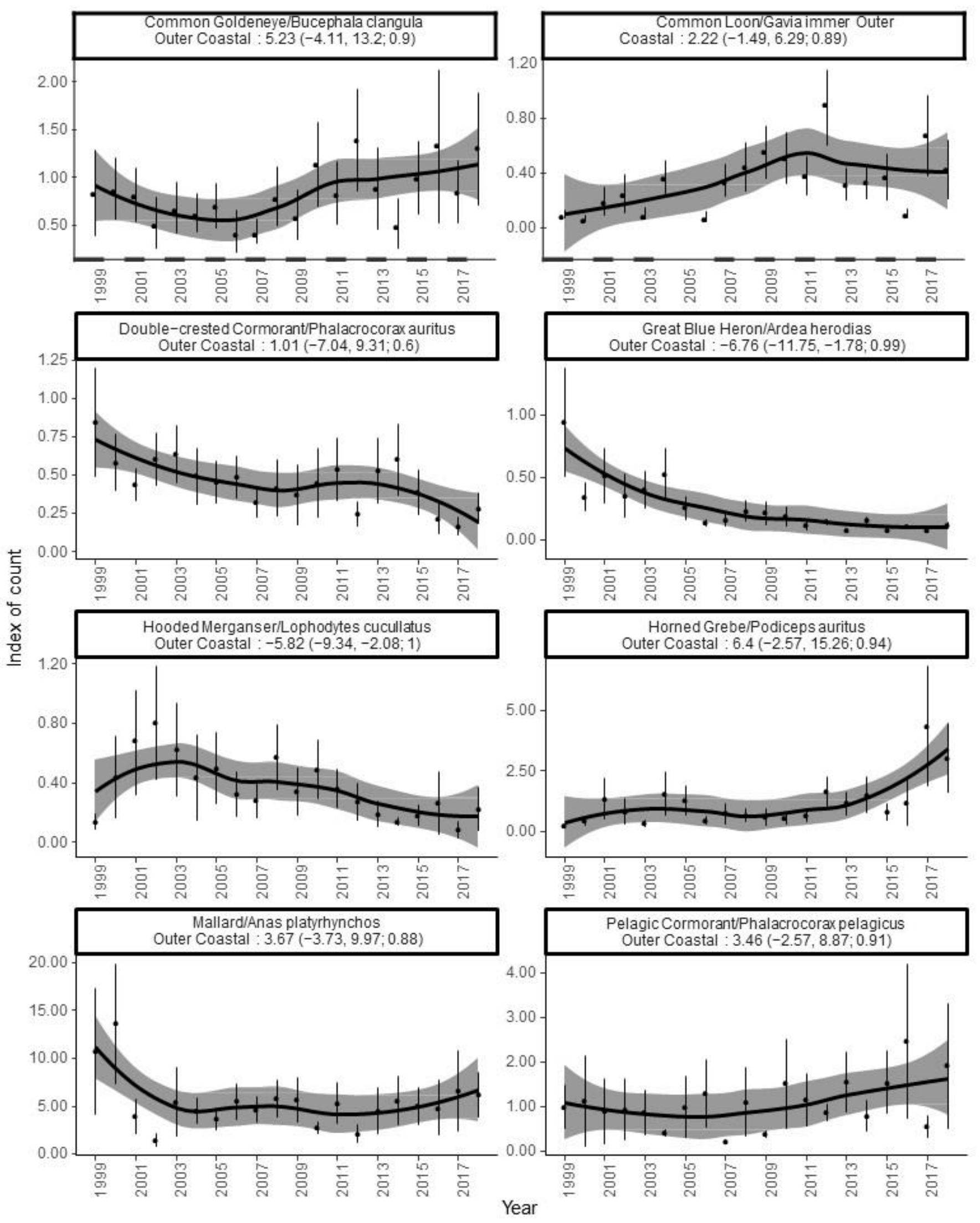




\section{Appendix 3}
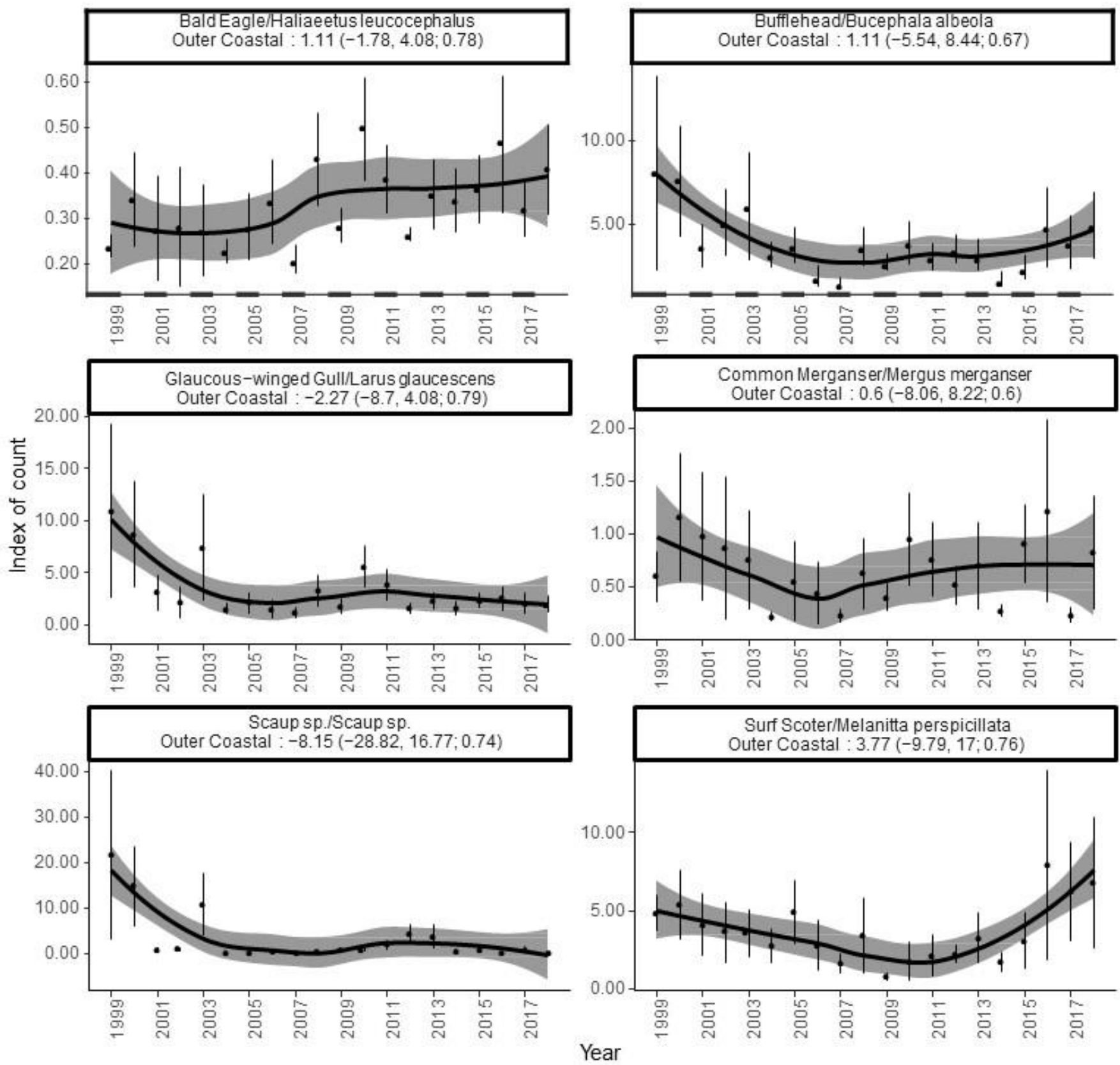